\title{
WPS4324
}

\author{
Policy Research Working Paper 4324
}

\section{Efficiency and Equity Impacts of Rural Land Rental Restrictions:}

\author{
Evidence from India
}

\author{
Klaus Deininger \\ Songqing Jin
}

Hari K. Nagarajan

The World Bank

Development Research Group

Sustainable Rural and Urban Development Team

August 2007 
Policy Research Working Paper 4324

\begin{abstract}
Recognition of the potentially deleterious implications of inequality in opportunity originating in a skewed asset distribution has spawned considerable interest in land reforms. However, little attention has been devoted to fact that, in the longer term, the measures used to implement land reforms could negatively affect productivity. Use of state level data on rental restrictions, together with a nationally representative survey from
\end{abstract}

India, suggests that, contrary to original intentions, rental restrictions negatively affect productivity and equity. The restrictions reduce the scope for efficiency-enhancing rental transactions that benefit poor producers.

Simulations suggest that, by doubling the number of producers with access to land through rental, from about 15 million currently, liberalization of rental markets could have far-reaching impacts.

This paper-a product of the Sustainable Rural and Urban Development Team, Development Research Group-is part of a larger effort in the group to assess the impact of land policies on poverty and economic growth. Policy Research Working Papers are also posted on the Web at http://econ.worldbank.org. The author may be contacted at kdeininger@ worldbank.org.

The Policy Research Working Paper Series disseminates the findings of work in progress to encourage the exchange of ideas about development issues. An objective of the series is to get the findings out quickly, even if the presentations are less than fully polished. The papers carry the names of the authors and should be cited accordingly. The findings, interpretations, and conclusions expressed in this paper are entirely those of the authors. They do not necessarily represent the views of the International Bank for Reconstruction and Development/World Bank and its affliated organizations, or those of the Executive Directors of the World Bank or the governments they represent. 


\title{
Efficiency and equity impacts of rural land rental restrictions:
}

\section{Evidence from India}

\author{
Klaus Deininger ${ }^{1}$, Songqing Jin ${ }^{1}$, and Hari K. Nagarajan ${ }^{2}$ \\ ${ }^{1}$ World Bank, Washington DC, USA \\ ${ }^{2}$ National Council for Applied Economic Research, New Delhi, India
}

We would like to thank A. Kaushik, T. Olsen, and S. Vats for excellent research assistance and S. Bery, D. Bradley, R. Buckley, E. Cook, J. Farrington, G. Feder, T. Hanstad, T. Haque, D. Lal, I. Lavadenz, K. Otsuka, S. Rozelle, two anonymous referees, and the editor managing this submission for insightful comments and suggestions. Financial support from the collaborative DFIDWorld Bank program on land policies and rural development is gratefully acknowledged. The views expressed in this paper are those of the authors and do not necessarily reflect those of the World Bank, NCAER, or DFID. 


\section{Introduction}

Researchers and policy-makers alike have come to realize that unequal access to opportunities arising from a skewed distribution of assets can be harmful for sustained long-term growth and thus of concern (Aghion et al. 1999, World Bank 2005). Not surprisingly in view of the important role and long-lasting impacts of historical land tenure arrangements (Banerjee and Iyer 2005), land reforms have occupied center stage in India's policy debates for a long time. Following successful abolition of intermediaries immediately after independence, award of property rights to sitting tenants through tenancy laws and expropriation with subsequent transfer of 'above-ceiling land' from large land owners to small farmers were main mechanisms to improve operational and ownership distribution of land. After a slow start, these policies alone transferred rights to almost $10 \mathrm{mn}$ ha of land, more than three times the land distributed in land reforms in Japan, Korea, and Taiwan together (King 1977).

Still, despite considerable progress in the past, such legislation has almost ceased to provide new land access and there is growing concern that, in today's changed context, maintaining restrictions on land rental could cause large efficiency losses by precluding efficiency-enhancing transfers of land to complement rural diversification. Given that, despite increased opportunities for rental, the share of Indian households participating in rental markets decreased from $26 \%$ in 1971 to $11 \%$ in 2001 and that in other countries rental markets have been found to significantly increase productivity (World Bank 2007), the impact of such restrictions could potentially be very large. This is countered by arguments that rental markets could, through 'reverse' tenancy, give rise to land concentration that is not only inefficient but would also disempower the poor by forcing them to offer their labor to monopsonistic landlords in local markets for casual labor that discriminate heavily on the basis of gender and caste.

To assess the functioning of land rental markets and explore efficiency and equity impacts of land rental restrictions, we use a model of producers who differ in endowments and skills and who face imperfect labor markets and transaction costs -further increased by policy-induced restrictions- in the land market. The model would lead us to expect three distinct effects, namely (i) a factor equalization effect whereby land markets will transfer land to farmers with lower land and higher labor endowments and with a higher level of ability; (ii) a diversification effect whereby increases in the non-agricultural wage rate will lead to an increase in land rental activity and a decrease in the equilibrium rental rate; and (iii) a transaction cost effect whereby higher levels of transaction costs -which may be policy-induced- will increase the share of producers remaining in autarky thus reducing the number of efficiency-enhancing land transfers. 
We use a nationally representative household panel spanning the 1982 to 1999 period to empirically test these predictions. As land is a state subject, we use cross-state variation in land reform legislation and its implementation to explore impacts of rental restrictions on land market functioning and outcomes A panel production function is used to obtain a measure of producers' ability to assess the productivity-impact of land rental. Results highlight that, contrary to what is often assumed, land rental markets help improve productivity and equity by transferring land to more productive and landless or land-poor households who, in the process, are able to improve their economic status. More importantly, the pro-poor nature of land markets has improved over time as wealth bias that had characterized such markets earlier has been eliminated. The fact that land rental is more active in locations with higher levels of non-farm activity supports the notion that it makes an important contribution to diversification of income sources in rural areas -in fact, the opportunities opened up through diversification could be a key factor underlying to help eliminate wealth-related barriers to rental market participation. Our analysis demonstrates that tenancy restrictions have not only significantly increased the share of producers who remain in autarky but also prevent land access by more efficient producers. In addition to the results being very robust, we also find that the magnitudes involved are very large. Simulations suggest that elimination of these restrictions could prompt an additional $40 \%-70 \%$ of producers to offer land for rental and, due to the smaller size of land rented in, double the number of those who are able to access land through rental. Using the mean difference between rental partners to make inferences on potential productivity impacts suggests that such impacts could be large as well. Thus, while implementing such laws has helped to obtain social gains in the past, maintaining them is an increasingly potent obstacle to realizing greater land access by those who are more productive and land-poor or landless and ways to improve on this may need to be explored.

The paper is structured as follows. Section two describes the history of land reforms and tenancy regulations in rural India, reviews evidence on the impact of land rental market restrictions and key differences between rural and urban land markets, and uses this to lay out a conceptual model and empirical strategy. Section three presents the data used and reviews descriptive statistics for policy variables and household characteristics. Section four contains econometric results for the production function and different models of land rental market participation and discusses the results and their robustness. Section five concludes by putting results into context and drawing out policy implications.

\section{Background and conceptual framework}

Land reform policy, through abolition of intermediaries, imposition of land ceilings, and regulation of tenancy contracts, played a key role in India from the moment it started its independent existence. A review key elements of land rental and ceiling laws, their implementation, and possible links between 
legislation and land market outcomes is followed by a conceptual model for households' land market participation and derivation of hypotheses that can be tested with the data at hand.

\subsection{Origins and nature of rural tenancy restrictions in India}

Under colonial rule, the main goal of India's land administration system was to obtain government revenue. The de facto award of land rights to revenue collectors (zamindars) in large parts of the country has consequences that affect development to this day (Banerjee and Iyer 2005). Agrarian reform was thus at the top of the immediate post-independence agenda and the fact that land was put under the competence of states rather than the Center led to considerable diversity in the timing, substance, and implementation of reforms across states. Abolition of rent-collecting intermediaries was tackled swiftly and successfully virtually everywhere. However, ceiling legislation -aiming to legislate a maximum land holding and force owners to dispose of all that was owned beyond this limit- and tenancy reform -which had the goal of limiting the rent to be paid for land and prohibiting tenant evictions- took a long time. The fact that implementation started in earnest only after 1972 allowed landlords to "prepare" by resuming self cultivation, evicting tenants or transforming them into wage workers, or implement spurious subdivisions, ${ }^{1}$ and enthusiasm for such reforms quickly disappeared after 1980 (Appu 1997).

The existence of wide variations in legislation across states provides ample scope to analyze the impact of such policies on observed outcomes. However, capturing the fine differences in timing, applicability, modalities of implementation, and definitions inherent in such legislation appears difficult if not impossible. Rather than trying to do so, we use the share of households who benefited from key policies as an indicator for policy-induced constraints to the operation of rental markets. Specifically, we construct for each state the share of households who were awarded tenancy rights and the share of ceiling surplus area that was actually transferred to beneficiaries. ${ }^{2}$ As none of the Indian states permit sub-leasing of lands to which tenants had received permanent rights and most states also impose restrictions on transfers of land received in the course of implementing ceiling legislation, this is proxies for direct restrictions on the operation of land rental markets. Both figures also provide an approximation for a state government's level of implementation effort, a variable that is exogenous to households' decisions but that was shown to be of great importance in earlier studies (Banerjee et al. 2002).

\footnotetext{
${ }^{1}$ Using census figures, Appu (1997) estimates that, to avoid having to give rights to tenants, landlords evicted about $30 \mathrm{mn}$ tenants or about one third of the total agriculturally active population. This is similar to evidence from other countries where landlords often succeeded- to evict tenants in anticipation of legislation to protect tenants against eviction or limit the rents they would have had to pay(Deininger 2003).

${ }^{2}$ We use area rather than beneficiaries because in some cases ceiling surplus land was distributed to a collective entity such as a cooperative so that the number of beneficiaries would be misleading. Also, the existence of large discrepancies between the amount of land expropriated and actually distributed -which is due to the fact that in some cases land that had been distributed could not occupied by beneficiaries or was taken back after some time- led us to focus on land actually distributed.
} 
Table 1 presents summary statistics by state for total agricultural area and 1980 population (columns 1 and 2) and our measures of land reform implementation around 1980 (columns 3 and 4). ${ }^{3}$ Relative emphasis across types of intervention, and the extent of implementation vary across states. More than $10 \%$ of households received tenancy rights in Kerala, Gujarat, West Bengal, and Maharashtra and more than $5 \%$ of area was distributed under ceiling surplus legislation in West Bengal, Andhra, Maharashtra, Rajasthan, and UP. Some states (e.g. West Bengal, Maharashtra) heavily relied on both measures, others (e.g. Andhra, Rajasthan and UP) focused exclusively on ceiling surplus, and some (e.g. Kerala and Gujarat) emphasized tenancy laws. Although -without detailed knowledge on content and implementation effort- the number of tenancy laws enacted is at best an imperfect proxy for the number and severity of restrictions on land rental, it is a useful point of reference. We thus include in the mean number of tenancy laws in each state (column 5) from Besley and Burgess (2000). One notes that the mean number of laws at any point amounts to 1.5, from none in Haryana to more than 4 in Tamil Nadu. The correlation between the number of laws and the number of tenants who received rights is low $(\rho=$ 0.28 ), supporting the notion that legal provisions alone had limited impact and implementation effort was required.

While we do not separate it out in the table, a more detailed look at the time dimension of these measures allows a number of conclusions (Kaushik 2005). First, land reform has been a major effort; up to 2000 , land reform laws resulted in the transfer of almost $10 \mathrm{mn}$ ha, $2.5 \mathrm{mn}$ ha under programs to redistribute of ceiling surplus land and $7.35 \mathrm{mn}$ ha under tenancy legislation. ${ }^{4}$ Second, after a spurt of land transfers in the 1970s and 1980s, progress has slowed down considerably; in fact between 1995/96 and $2003 / 04$, i.e. for almost a decade, progress in awarding land rights to tenants had come to a complete standstill. $^{5}$

\subsection{Tenancy legislation and rent controls: International evidence}

Even though empirical evidence on the impact of rent ceilings and other forms of tenancy control in rural areas is limited, the issue has been analyzed in urban contexts where rent control is a textbook example for policies that can be effective to transfer resources in the short term but will be associated with inefficiencies in the medium to long run (Arnott 2003). The key reason, which also formed the basis for analytical approaches, is that, by fixing rents below their equilibrium level, controls reduce the supply of

\footnotetext{
${ }^{3}$ Wherever available, the level of the respective variables in 1980 and 1998, respectively, is used as a right hand side variable in the regressions.

${ }^{4}$ The amount of land involved is much larger than what was redistributed in other Asian land reforms such as Japan ( 2 mn has), Korea ( 0.58 mn has) and Taiwan (0.24 mn has). In terms of total area distributed, this puts India on par with Mexico which, in a much more land-abundant setting, and starting in 1917, managed to distribute slightly more than $13 \mathrm{mn}$ ha (Deininger 2003).

${ }^{5}$ The increment in ceiling surplus land transferred during the period amounted to only 10,800 ha which is only about one tenth of the land declared ceiling surplus which had not been distributed. The fact that all the remainder remains tied up in litigation suggests that further progress in achieving redistribution of ceiling land could be slow -it would take almost 90 years to dispose of remaining ceiling surplus cases if the current pace is maintained- and that, by clogging up the court system and preventing it from quickly dispensing justice in other urgent matters, the ceiling legislation may impose external effects beyond land rental markets (Moog 1997).
} 
new housing or maintenance of existing units by landlords who face an artificially reduced price (Gyourko and Linneman 1990). Thus, although they transfer resources from landlords to sitting tenants at the time of imposition, they make access to rental property more difficult thereafter (Basu and Emerson 2000). With a constant or decreasing number of beneficiaries and an increasing number of new entrants who need to access to land in distorted markets, social cost of maintaining land rental restrictions will increase over time (Glaeser 2002). While rent controls may be useful to deal with emergencies in the short term, other policies may be more effective (Malpezzi and Ball 1991), have fewer undesirable sideeffects including reduced tenant mobility (Munch and Svarer 2002), and can be better targeted.

While there is little empirical evidence on the impact of rental restrictions in rural areas, a number of reasons would lead one to expect that it will go far beyond the price effects on which the urban literature has focused. First, due to labor market imperfections, the way in which rural land is used will have a clear impact on productive efficiency (Binswanger et al. 1995). Second, supply of housing to urban markets will be less elastic as owners can not revert to own- or wage labor-based cultivation, an issue that has been highly relevant in India (Appu 1997). Third, as rural rents are generally defined as an in-kind output share, contract terms will be less flexible than urban ones, limiting the scope for circumventing them by adjusting rental rates (Basu and Emerson 2003). Finally, rights given to tenants are heritable but non-transferable and still require rent payment to the landlord, thus reducing both parties' incentives for land-related investments and the scope to increase allocative efficiency through sub-leasing. ${ }^{6}$

While all of these issues could significantly add to the long-term cost of land reforms, they have not featured prominently in the large literature on Indian land reforms (Warriner 1969, Thorner 1976, Besley and Burgess 2000, Banerjee et al. 2002). Exploring this by assessing how land rental markets work and to what extent they are affected by tenancy restrictions will allow us to get an indication of such cost and help put the policy debate on land markets in India on a more robust empirical footing.

\subsection{Conceptual framework}

A key rationale for producers to engage in land markets is the desire to adjust for differences in their existing endowments of land and family labor. Following similar models in the literature (Carter and Yao 2002), let household $i$ be endowed with fixed amounts of labor $\left(\bar{L}_{i}\right)$ and land $\left(\bar{A}_{i}\right)$, and a given level of agricultural ability $\left(\alpha_{i}\right)$. Agricultural production follows a production function $f\left(\alpha_{i}, l_{i, a}, A_{i}\right)$ with standard

\footnotetext{
${ }^{6}$ The tenant will be unlikely to invest as doing so will result in an immediate increase of the rent whereas investment by the landlord is unlikely as part of the benefits will go to the tenant.
} 
properties, i.e. $f^{\prime}>0, f^{\prime \prime},<0$ with respect to all arguments and $f{ }^{\prime \prime}{ }_{I A}>0 .{ }^{7}$ Relative land scarcity, together with the cost of supervising labor (Frisvold 1994) makes wage-labor based cultivation undesirable in equilibrium (Binswanger et al. 1995), implying that households allocate their labor endowment between farming their own land $\left(l_{i, a}\right)$ and off-farm employment $\left(l_{i, o}\right)$ at an exogenous wage $\left(w_{i}\right)$. Renting of land incurs transaction costs $T C^{i n}$ for renting-in and $T C^{\text {out }}$ for renting-out because of the need to obtain information on market conditions, to negotiate and enforce payments, and the presence of regulations that restrict transferability or completely outlaw certain contract types. We assume transaction costs to be proportional to the size of land transferred allow households to structure rental contracts in a way that allows those lacking liquidity to enter into arrangements to allow them to defer rental payments until the harvest. With this, household $i$ 's decision problem is to choose $A_{i}, l_{i, a}$ and $l_{i, o}$ to solve

$$
\begin{aligned}
& \quad \operatorname{Max}_{i, a}, l_{i, o}, A_{i} \\
& \text { s.t. } \\
& \qquad l_{i, a}+l_{i, o} \leq \bar{L} \\
& \\
& \left.\quad l_{i, a}, l_{i, o}, A_{i}, l_{i, a}, A_{i}\right)+w l_{i, o}-I^{\text {in }}\left[\left(A_{i}-\bar{A}_{i}\right)\left(r+T C^{\text {in }}\right)\right]+I^{\text {out }}\left[\left(\bar{A}-A_{i}\right)\left(r-T C^{\text {out }}\right)\right]
\end{aligned}
$$

where $p$ is the price of agricultural goods, $r$ is the rental rate, $A_{i}$ is the operational land size, $I^{\text {in }}$ is a indicator variable for rent-in (=1 for rent-in, 0 otherwise), $I^{\text {out }}$ is an indicator for rent-out (=1 for rentout, and 0 otherwise), $T C^{\text {in }}$ and $T C^{\text {out }}$ are transaction costs, and all other variables are as defined above. Assuming that the restrictions in (1a) hold with equality, the optimal choices of $l_{i, a}{ }^{*}, l_{i, o}{ }^{*}$ and $A_{i}{ }^{*}$ will solve the first order conditions (FOC) of problem (1), i.e.

$$
p f_{l_{i}, a}\left(\alpha_{i}, l_{i, a}, A_{i}\right)=w
$$

and for households who rent in $\left(\mathrm{A}^{*}>\bar{A}_{i}\right), \quad p f_{A_{i}}\left(\alpha_{i}, l_{i, a}, A_{i}\right)=r+T C^{i n}$

and for households who rent out $\left(\mathrm{A}^{*}<\bar{A}_{i}\right), \quad \quad p f_{A_{i}}\left(\alpha_{i}, l_{i, a}, A_{i}\right)=r-T C^{\text {out }}$

and for autarkic households $\left(\mathrm{A}^{*}=\bar{A}_{i}\right), \quad r-T C^{\text {out }}<p f_{A_{i}}\left(\alpha_{i}, l_{i, a}, A_{i}\right)<r+T C^{\text {in }}$

The first order conditions allow derivation of three empirically testable propositions as follows with more detailed proofs to be found in the appendix.

\footnotetext{
${ }^{7}$ Note that, $f\left(\alpha_{i}, l_{i, a}, A_{i}\right)$ is subject to constant return to scale. For example, in the Cobb-Douglass case, $f\left(\alpha_{i}, l_{i, a} A_{i}\right)=\alpha_{i}^{1-\beta_{1}-\beta_{2}} l_{i, a}^{\beta_{1}} A_{i}^{\beta_{2}}$. As ability is not tradable, $f\left(l_{i, a} A_{i}\right)=l_{i, a}^{\beta_{1}} A_{i}^{\beta_{2}}$ is subject to decreasing return to scale in land and labor (Conning and Robinson 2007).
} 
Proposition 1: The amount of land rented in (out) is strictly increasing (decreasing) in households' agricultural ability, $\alpha_{i}$, and strictly decreasing (increasing) in the land endowment $\bar{A}_{i}$. Land rental will transfer land to efficient, but land-poor producers, thereby contributing to higher levels of productivity and more efficient factor use in the economy. For households renting in or out land, this proposition can be derived by totally differentiating both sides of equations (2) and (3) or (2) and (4) with respect to $\alpha_{i}$ or $\bar{A}_{i}$. Manipulating terms yields $\partial A_{i}{ }^{*} / \partial \alpha_{i}>0$ (or $\partial A_{i}{ }^{*} / \partial \bar{A}<0$ ). Since $a_{i}^{\text {in }}$ or $a_{i}^{\text {out }}$, the amount rented in or rented out, respectively is defined as either $A_{i}{ }^{*}-\bar{A}_{i}$ or $\bar{A}_{i}-A_{i}{ }^{*}$, the result for $a_{i}{ }^{\text {in }}$ and $a_{i}{ }^{\text {out }}$ follows.

Proposition 2: The presence of transaction costs defines two critical ability levels $\alpha_{l}\left(T C^{\text {out }}, ..\right)$ and $\alpha_{u}\left(T C^{i n}, ..\right)$ such that households with ability $\alpha_{i} \in\left[\alpha_{l}, \alpha_{u}\right]$ will remain in autarky. Any increase in $T C^{i n}$ or $T C^{\text {out }}$ will expand the autarky range, thus reducing the number of producers participating in rental markets and the number of efficiency-enhancing land transactions. Compared to a situation with no transaction cost, this will decrease productivity and social welfare. To see this, note that the cutoff points $\alpha_{l}$ and $\alpha_{u}$ can be obtained from (4) and (3) by setting $A_{i}{ }^{*}=\bar{A}_{i}$ and $l_{i, a}=l_{i, a}^{*}$ where $l_{i, a}^{*}$ is autarkic household i's optimal amount of labor in agricultural production which can be derived from (2) at $A_{i}{ }^{*}=\bar{A}_{i}$. Defining $f\left(\alpha_{i}, l_{i, a}, A\right)=\alpha_{i}^{1-\beta_{1}-\beta_{2}} l_{i, a}^{\beta_{1}} A_{i}^{\beta_{2}}$, we can solve for $\alpha_{l}$ and $\alpha_{u}$ explicitly as $\alpha_{l}=\left(\frac{r-T C^{\text {out }}}{\beta_{2}\left(l_{i, a}^{*}\right)^{\beta_{1}} \bar{A}^{\beta_{2}-1}}\right)^{\frac{1}{1-\beta_{1}-\beta_{2}}}$ and $\alpha_{u}=\left(\frac{r+T C^{i n}}{\beta_{2}\left(l_{i, a}^{*}\right)^{\beta_{1}} \bar{A}^{\beta_{2}-1}}\right)^{\frac{1}{1-\beta_{1}-\beta_{2}}}$. Differentiation of $\alpha_{l}$ or $\alpha_{u}$ with respect to the corresponding transaction cost variable $T C^{\text {out }}$ or $T C^{\text {in }}$ then yields the result of interest.

Proposition 3: Increases of the exogenously given wage for off-farm employment will imply that higher amounts of land are transacted in rental markets as households with low agricultural ability who join the off-farm labor market will supply more land. This leads to a decrease in the equilibrium rental rate which will prompt high-ability workers (specializing in agricultural production) to rent in more land.

To derive this proposition, assume without loss of generality that the economy contains $n$ households who are endowed with identical amounts of land and labor $\bar{A}$ and $\bar{L}$ but different levels of farming ability $\alpha_{i}$ and that the latter is uniformly distributed between $\underline{\alpha}$ and $\bar{\alpha}$. We also assume that, with fixed setup costs, households give up agricultural production completely and rent out all their land if the amount of labor to be allocated optimally to agricultural production is less than $l_{a}^{c}$. To be able to derive a closed form solution, we abstract from transaction costs (i.e. letting $T C^{i n}=T C^{o u t}=0$ ) and use an explicit 
functional form $f\left(\alpha_{i}, l_{i, a}, A\right)=\alpha_{i}^{1-\beta_{1}-\beta_{2}} l_{i, a}^{\beta_{1}} A_{i}^{\beta_{2}}$. With an exogenous wage $w$ and prices normalized to 1 , the rental rate $r$ will be determined endogenously and first order conditions (dropping $i$ for notational clarity) simplify to

$$
f_{l_{a}}^{\prime}=\alpha^{\left(1-\beta_{1}-\beta_{2}\right)} \beta_{2} A^{\beta_{1}} l_{a}^{\left(\beta_{2}-1\right)}=w
$$

and

$$
f_{A}^{\prime}=\alpha^{\left(1-\beta_{1}-\beta_{2}\right)} \beta_{1} A^{\left(\beta_{1}-1\right)} l_{a}^{\beta_{2}}=r
$$

As $A^{*}$ is proportional to households' farming ability $\alpha$, the market clearing condition can be expressed as $\int_{\underline{\alpha}}^{\bar{\alpha}} A^{*} d \alpha=n \bar{A}$, which together with (6) and (7) can be used to solve for $A^{*}, l_{a}^{*}$ and $r^{*}$ as $A^{*}=\alpha \frac{2 n \bar{A}}{\left(\bar{\alpha}^{2}-\underline{\alpha}^{2}\right)}, l_{a}^{*}=\alpha\left(\frac{\bar{\alpha}^{2}-\underline{\alpha}^{2}}{2 n \bar{A}}\right)^{\left(\frac{\beta_{1}}{\beta_{2}-1}\right)} w^{\left(\frac{1}{\beta_{2}-1}\right)} \beta_{2}^{\left(\frac{1}{1-\beta_{2}}\right)}$ and $r^{*}=\left(\frac{\bar{\alpha}^{2}-\underline{\alpha}^{2}}{2 n \overline{\bar{A}}}\right)^{\left(\frac{\beta_{1}+\beta_{2}-1}{\beta_{2}-1}\right)} w^{\left(\frac{1}{\beta_{2}-1}\right)} \beta_{2}^{\left(\frac{1}{1-\beta_{2}}\right)} \beta_{1}$

Setting $l_{a}{ }^{*}=l_{a}^{c}$ allows to solve for the critical level of ability $\alpha_{c}$ below which households will rent out all their land endowment. For households who continue farm production, we solve for the new optimal operational land size $\left(A^{* *}\right)$ and new rental rate $\left(r^{* *}\right)$ based on $(6),(7)$ and the new market clearing condition $\left(\int_{\alpha_{c}}^{\bar{\alpha}} A^{* *} d \alpha=n \bar{A}\right)$. Setting $A^{* *}=\bar{A}$ allows us to solve for the farming ability by household who remain autarkic $\alpha_{a u}$. Taking derivatives of $\alpha_{c}, A^{* *}, \alpha_{a u}$ and $r^{* *}$ with respect to $w$ yields: $\partial \alpha_{c} \partial w>0$, $\partial A^{* *} / \partial w>0, \partial \alpha_{a u} / \partial w<0$ and $\partial r^{* *} / \partial w<0$, suggesting that, as off-farm opportunities increase, a larger number of households will drop farm production and rent out all their endowment, the equilibrium rental rate will decrease, households who remain in agricultural production cultivate more land, and a greater number of households will rent in land.

\subsection{Estimation strategy}

Equations (2)-(5) indicate that producers' decision to enter land rental markets depends on their marginal productivity in autarky, $\operatorname{MP}(\bar{A})$ as compared to the rental rate to be paid $r^{\text {in }}(T)$ or received $r^{\text {out }}(T)$ which is a function of transaction costs. Formally, the three regimes are characterized by

$$
\left.\begin{array}{ll}
\text { I. Rent - out regime }\left(\mathrm{A}_{\mathrm{i}}^{*}>\overline{\mathrm{A}}_{\mathrm{i}}\right): & M P(\bar{A})+\varepsilon_{i}<r\left(T C^{\text {out }}\right) \\
\text { II. Autarky regime }\left(\mathrm{A}_{\mathrm{i}}^{*}=\overline{\mathrm{A}}_{\mathrm{i}}\right): & r\left(T C^{\text {out }}\right)<M P(\bar{A})+{ }_{i}<r\left(T C^{\text {in }}\right) \\
\text { III.Rent - in regime }\left(\mathrm{A}_{\mathrm{i}}^{*}<\overline{\mathrm{A}}_{\mathrm{i}}\right): & M P(\bar{A})+\varepsilon_{i}>r\left(T C^{\text {in }}\right)
\end{array}\right\}
$$

A producer's marginal product $M P(\bar{A})$, will depend on his or her ability $(\alpha)$, endowment with land $(\bar{A})$, family labor $(\bar{L})$, assets $(K)$, and the opportunity cost of labor which will be affected by the level of education $(E)$ and the presence of opportunities in the local off-farm labor market $(O)$. Defining a well- 
behaved net earning function $g(\alpha, \bar{A}, \bar{L}, K, E, O)$ with first derivative $g^{\prime}($ (), we can write a linear version of the latter as $M P(\bar{A})=g^{\prime}(\alpha, \bar{A}, \bar{L}, K, E, O)=\beta_{0}+\beta_{1} \alpha+\beta_{2} \bar{A}+\beta_{3} \bar{L}+\beta_{4} K+\beta_{5} E+\beta_{6} O$. Transaction costs are expected to depend on policy variables $S$, household characteristics $Z$, and a time dummy $D^{99}$. Defining an index variable $y_{i}$ such that $y_{i}=1$ if $\mathrm{A}^{*}<\bar{A} ; y_{i}=2$ if $\mathrm{A}^{*}=\bar{A} ; y_{i}=3$ if $\mathrm{A}^{*}>\bar{A}$, we can rewrite (8) as an ordered probit model that can be estimated using maximum likelihood methods.

$$
\left.\begin{array}{rl}
\operatorname{Prob}\left(y_{i}=1\right)= & \Phi\left\{\varepsilon_{i}<\eta_{0}+\eta_{1} S+\eta_{2} Z+\eta_{3} D^{99}-\beta_{0}-\beta_{1} \alpha-\beta_{2} \bar{A}-\beta_{3} \bar{L}-\beta_{4} K-\beta_{5} E-\beta_{6} O\right\} \\
\operatorname{Prob}\left(y_{i}=2\right)= & \Phi\left\{\eta_{0}+\eta_{1} S+\eta_{2} Z+\eta_{3} D^{99}-\beta_{0}-\beta_{1} \alpha-\beta_{2} \bar{A}-\beta_{3} \bar{L}-\beta_{4} K-\beta_{5} E-\beta_{6} O<\varepsilon_{i}\right. \\
& \left.<\delta_{0}+\delta_{1} S+\delta_{2} Z+\delta_{3} D^{99}-\beta_{0}-\beta_{1} \alpha-\beta_{2} \bar{A}-\beta_{3} \bar{L}-\beta_{4} K-\beta_{5} E-\beta_{6} O\right\} \\
\operatorname{Prob}\left(y_{i}=3_{i}\right)= & \Phi\left\{\varepsilon_{i}>\delta_{0}+\delta_{1} S+\delta_{2} Z+\delta_{3} D^{99}-\beta_{0}-\beta_{1} \alpha-\beta_{2} \bar{A}-\beta_{3} \bar{L}-\beta_{4} K-\beta_{5} E-\beta_{6} O\right\}
\end{array}\right\}
$$

Variables we expect to affect marginal productivity are agricultural ability $(\alpha)$, the derivation of which will be discussed below, a dummy for landlessness and the log of the land endowment to represent $\bar{A}$, the number of members in the 14-60 and below 14-year age group to represent $\bar{L}$, the value of assets and the share of agricultural assets (livestock, implements, and agricultural structures) for $K$, the head's age (as a proxy for experience) and a dummy for primary education to represent human capital $E$, and mean village income $O$ to represent wage labor opportunities in off-farm labor markets. Transaction cost of land rental participation are affected by producer's caste status, $(Z)$, a time dummy $\left(D^{99}\right)$, and land policy $(S)$ which is proxied by either the share of households who were recognized under tenancy reform, the share of area distributed under ceiling legislation, or the number of tenancy laws enacted as discussed earlier.

The propositions from our model allow making predictions on the signs of individual coefficients. The factor equalization from proposition 1 implies that rental markets will transfer land to more productive producers $\left(\beta_{1}>0\right)$ with lower levels of land endowments $\left(\beta_{2}<0\right)$ and more family labor $\left(\beta_{3}>0\right)$. The hypothesis of wealth bias in rental markets, possibly due to credit market imperfections, translates into $\beta_{4}>0$. Diversification effects implied by proposition 3 suggest that producers with higher levels of education have better off farm opportunities and will be less likely to rent in land $\left(\beta_{5}<0\right)$ and that higher levels of non-agricultural wages, proxied by $O$, will make renting in less likely $\left(\beta_{6}<0\right)$.

Proposition 2 implies that, by moving the cut-off points where producers shift from renting out to autarky and from autarky to renting in, respectively, rental market restrictions expand the range of autarky but do not affect producers' marginal product. ${ }^{8}$ We thus expect $\eta_{1}>0$ and $\delta_{1}<0$, respectively. By the same logic, higher transaction costs for producers from scheduled and backward castes imply $\eta_{2}>0$, and $\delta_{2}<0$

\footnotetext{
${ }^{8}$ It is intuitive that rental restrictions will directly affect whether or not households participate but, unless there are selectivity issue, are unlikely to affect producers' marginal productivity. Indeed testing for selectivity of rental market participation, by including rental restrictions in the marginal product equation as well, does not produce conclusive results.
} 
while a reduction over time in transaction costs due to better access to information implies $\eta_{3}<0$ and $\delta_{3}>0$.

A key element of the regression (8) is households' agricultural ability $\alpha$. As the data available are a panel of households and their offspring who were observed in 1982 and again in 1999, we can recover this parameter from a panel production function using household (or dynasty) fixed effects to proxy for ability (Deininger and Jin 2007). Let technology be represented by the Cobb-Douglas production function

$$
Q_{i j t}=\exp \left(\alpha_{i}+\alpha_{j}\right) A_{i j t}{ }^{\theta_{1}} L_{i j t}^{\theta_{2}} K_{i j t}^{\theta_{3}} X_{i j t}^{\theta_{4}} \exp (\phi t)
$$

where $Q_{i j t}$ is the value of agricultural output produced by household i in village $j$ in year $t ; A_{i j t}, L_{i j t}$ and $K_{i j t}$, $X_{i j t}$ are total cultivated area, labor for crop production, value of agricultural assets, and amounts of chemical fertilizer, organic manure, pesticides, and seeds, $\theta_{1}, \theta_{2}, \theta_{3}$, and $\theta_{4}$ are technical coefficients, $\alpha_{j}$ is a time invariant village level parameter reflecting, among others, access to markets, infrastructure, and other time invariant factors such as climate, $\alpha_{\mathrm{i}}$ is the time invariant household fixed effect which we use to measure of ability, and $\mathrm{t}$ is a time dummy so that $\exp (\phi t)$ measures productivity changes over time. To estimate this, we let $\alpha_{i j}=\alpha_{i}+\alpha_{j}$, take logarithms of both sides, and add an iid error term to obtain

$$
q_{i j t}=\alpha_{i j}+\theta_{1} a_{i j t}+\theta_{2} l_{i j t}+\theta_{3} k_{i j t}+\theta_{4} x_{i j t}+\phi t+\varepsilon_{i j t}
$$

where lower case letters are logarithms. With multiple observations per household, we can subtract means

$$
q_{i j t}-\bar{q}_{i j}=\alpha_{i j}-\bar{\alpha}_{i j}+\theta\left(Z_{i j t}-\bar{Z}_{i j}\right)+\phi(t-\bar{t})+\varepsilon_{i j t}-\bar{\varepsilon}_{i j}
$$

where $\boldsymbol{Z}_{i j t}$ is a vector including $a, l, k, x$ with coefficients $\boldsymbol{\theta}$. As $\alpha_{i j}-\bar{\alpha}_{i j}=0$, this can be simplified to

$$
q_{i j t}-\bar{q}_{i j}=\theta\left(Z_{i j t}-\bar{Z}_{i j}\right)+\phi(t-\bar{t})+\varepsilon_{i j t}-\bar{\varepsilon}_{i j}
$$

This can be used to obtain $\hat{\alpha}_{i j}$, composed of a producer's idiosyncratic ability $\alpha_{i}$ and unobserved village attributes $\alpha_{j}$. Letting the latter be the average of household fixed effect in the village $\hat{\alpha}_{j}=\left(\sum_{i} \hat{\alpha}_{i j}\right) / n_{j}$ (Mundlak 1961) allows to obtain $\hat{\alpha}_{i}$, the producer-specific effect by subtracting $\hat{\alpha}_{j}$ from $\hat{\alpha}_{i j} \cdot 9$

\section{Data sources and descriptive evidence}

\footnotetext{
${ }^{9}$ An alternative approach is to use a stochastic frontier production function to determine producers' level of technical efficiency in each of the periods. This assumes that the disturbance term is composed of two additive components $v_{i}$ and $u_{i}$ where $v_{i}$ is pure white noise and $u_{i} \sim N^{+}\left(0, \delta_{u}{ }^{2}\right)$ captures producers' level of technical inefficiency $T E_{i}=\exp \left(-u_{i}\right)$ (Coelli 1995). While the strong distributional assumption and the fact that $u_{i}$ captures other shocks imply that this is inferior to the panel approach, the fact that a large number of households dropped out of the panel makes this an attractive alternative which we use as a robustness check for our results below.
} 
Before discussing the econometric results, we describe the data by presenting evidence on socioeconomic characteristics as well as land market participation and changes in these variables over time. This allows us to explore changes of the economic structure, growth, and asset accumulation by individuals and at the village level. Concerning rental markets, our interest is to find out whether our hypotheses are supported by descriptive evidence or whether, possibly as a result of "reverse tenancy" rental markets lead to transfers from small to larger producers rather than to land-poor ones.

\subsection{Household characteristics}

The data used in the analysis come from two rounds of NCAER's ARIS/REDS survey conducted in 1982 and 1999, respectively. This survey, the first rounds of which were implemented in 1968-71 to evaluate the impact of an agricultural development program, covers all of India's major states. Even though the first round sample, stratified by farm size and wealth class, was limited to project areas, the survey was expanded in 1982 to make it more representative at the national level, covering slightly less than 5,000 households (Foster and Rosenzweig 1996). The 1999 sample contains the 1982 sample and replacements for those no longer present. If the original household had split, all of the households belonging to the same dynasty in the original village plus a sub-sample of successor households outside the village were interviewed, bringing the total to about 7,500 households (Foster and Rosenzweig 2004).

Table 2 reports descriptive statistics for the whole country and its four main regions in both periods. ${ }^{10}$ We note that there has been a marked increase in educational attainment, as illustrated by the fact that the share of household heads with primary schooling completed increased from about $26 \%$ in 1982 to $50 \%$ in 1999 . The gap that had earlier separated Northern and Southern states also narrowed considerably. At the same time, population growth led to a decline in the average land endowment, from 3.3 ha in 1982 to 2.1 ha in 1999 , and a small increase in landlessness, from $22 \%$ to $24 \%$. Average household size decreased, from 6.9 to 6.0 , with about 4 in the 14 to 60 age category, 0.4 aged above 60 , and 2.4 as compared to 1.8 below the age of 14 . The share of female headed households is, with $6.8 \%$, almost the same in both periods, although female headship is more pronounced in the South than in other regions.

Survey results also point towards an annual increase of per capita income of $3.1 \%$ during the period under concern. This aggregate masks pronounced differences across regions with the South having caught up and even replaced the North as the region with the highest income in the second period. Use of the information from the listing exercise allows us to compute the Gini coefficient for self-assessed income in a way that includes all households in the sampled villages. With a Gini coefficient of 0.32 in

\footnotetext{
${ }^{10}$ We group states into four regions as follows: The North includes the states of Haryana, Himachal Pradesh, Punjab, and Uttar Pradesh; the West includes Gujarat, Maharashtra, Madhya Pradesh, and Rajasthan; the East includes Assam, Bihar, Orissa, and West Bengal; and the South includes Andhra Pradesh, Karnataka, Kerala, and Tamil Nadu.
} 
the first and 0.31 in the second period, inequalities in income remain modest and have not appreciably increased between the two periods. The overall improvement in living standards as illustrated by increased income is mirrored by a significant rise in asset values of approximately $6 \%$ per year. ${ }^{11}$ It is worth noting that, with a Gini coefficient of 0.60 in 1982, inequality in assets is higher than income inequality, as found in other parts in the world as well. However, this coefficient has actually decreased to 0.56 in the second period. While overall asset endowments have increased, the broad composition of households' asset portfolio shows greater stability; the house and consumption durables make up the largest share in both periods (57.5\% and 56.9\%, respectively in 1982 and 1999), followed by financial and off-farm assets (26.7\% and 23.2\%), and farm assets including livestock (15.8\% and 19.9\%).

The bottom panel illustrates the diversification of income sources achieved during the period by highlighting the share of households who participated in various activities, noting that households generally rely on more than just one income source. Three observations are of particular interest. First, despite a drop by about 7 and 15 percentage points in the share of households engaging in crop and livestock production, respectively (from $70 \%$ to $63 \%$ for crop and from $78 \%$ to $63 \%$ for livestock), self employment in agriculture remains the most important source of employment in India's rural economy. The fact that this is followed by agricultural wage employment, the share of which has actually increased over the period (from $37.6 \%$ to $43.3 \%$ ) points to a continued importance of agriculture and the importance of agricultural wage employment for the landless. A second finding of interest is that the share of households engaging in self-employment in rural India has been more or less constant, implying that growth of the rural non-farm sector has been just large enough to absorb population growth. This contrasts with other countries where the rural non-farm economy developed as a result of out-migration of labor or due to households taking up non-farm self employment. In fact, according to our data, the main source of income diversification was growth of non-farm wage employment, participation in which increased from $8.6 \%$ in 1982 to $20 \%$ in 1999 . This fact, which has also been observed elsewhere (Foster and Rosenzweig 2004), could result from the government's emphasis on creating rural employment through mechanisms ranging from direct subsidies for firms to set up in remote areas to industrial and labor market regulation such as small scale reservation acts (Besley and Burgess 2004).

\subsection{Operation of land rental markets}

To provide evidence on the extent to which our hypotheses on land markets are borne out descriptively, Table 3 presents key variables by households' land rental participation status (rent in, rent out, or autarky). It points towards a large increase in the level of land market activity over the period; from 5.3\%

\footnotetext{
${ }^{11}$ While part of this increase may be due to improvements in the survey instrument that resulted in better measurement of assets in the second period, it is impossible to test this hypothesis as disaggregated data for 1982 were not available.
} 
and $2 \%$ for renting out and renting in, respectively, in 1982, the share of market participants has increased to $10.7 \%$ and $4.1 \%$, in $1999 .{ }^{12}$ Descriptive figures also support the propositions from our model and the notion of better rental market functioning in the second, as compared to the first period.

Comparing the per capita land endowment for land owners who either remained in autarky $(0.51$ ha and 0.36 ha in 1982 and 1999, respectively), rented in (0.28 ha and 0.20 ha), or rented out ( 0.68 ha and $0.64 \mathrm{ha}$ ) in the two periods illustrates that, in both periods, rental provided opportunities for relatively land-scarce and labor-abundant households to gain access to land. Land markets transferred land from households with more educated and female heads to male headed ones with lower educational attainment. We also note that the share of landless who had gained access to land through rental markets increased from $12 \%$ in the first to $37 \%$ in the second period, suggesting a marked expansion of outreach towards this group over time. Noting that our sample represents about $130 \mathrm{mn}$ rural households, in 1999 about 15 mn households -a quarter of them landless- were able to use markets as a means to get access to land. This figure is not only much larger than the number of those who got access to land through land reform but also that, given the magnitudes involved, even policies with "modest" impact on the functioning of land rental markets could have implications for a large number of households.

Comparing levels of consumption and assets for households who differ in the nature of their land market participation reinforces the notion that rental provides opportunities for poor segments of the population to access productive resources and thereby improve their well-being, especially in the second period. The value of all assets owned by rent-in households in 1999 is, with Rs. 33,839, more than 25\% below the average, compared to asset ownership that is similar to the mean for autarkic households and about 33\% higher than the mean for those renting out, supporting the notion that it is the asset-poor who benefit from the access to land which rental markets provide. The narrowing of the gap between rent-in and average households with respect to per capita expenditure supports the hypothesis of land markets making a positive contribution to the livelihood of participants. Finding significant differences in the composition of the asset portfolio between rent-in and rent-out households, with the former having relatively more of their wealth in farming and livestock and the latter in off-farm and financial assets is not too surprising.

While higher participation in crop and livestock production by those renting in should not come as a surprise, the high share of renters engaging in (agricultural) wage employment suggests that land rental provides wage laborers with opportunities to earn additional income. At the same time, the fact that

\footnotetext{
${ }^{12}$ While this is a large change, the level of rental market activity increased more rapidly, and in a shorter period, in other Asian countries such as China or Vietnam, despite the fact that the more egalitarian land ownership distribution in these countries would put greater limits on the potential of land markets to equalize operational holdings than in India. In Vietnam, the share of households renting in increased form $3.8 \%$ to $15.8 \%$ in the 5-year period between 1993 and 1998 (Deininger and Jin 2007). In China, the same figure increased from $2.3 \%$ in 1996 to 9.4 in 2001 (Deininger and Jin 2005).
} 
-in contrast to what was found in 1982- non-farm self employment is much higher among rent-in households than either the mean or those who remained in autarky suggests that land rental is not an obstacle to participation in the rural non-farm economy. To the contrary, renting may provide an opportunity to accumulate experience and capital to replace the "agricultural ladder" (Spillman 1919) with a general increase in occupational mobility including the non-farm sector (Alston and Ferrie 2005).

\section{Econometric evidence}

We find that measures to implement land reform, whether proxied by the number of laws passed, the area transferred under ceiling legislation, or the number of beneficiaries from tenancy acts, constrain rental market activity, thereby reducing both equity and efficiency. They make it more difficult for producers with high ability, including the landless, to gain access to land while at the same time constituting an obstacle for giving up farming by those with low ability who want to get out of agriculture.

\subsection{Production function}

To obtain a measure of households' or dynasties' agricultural ability, a production function, coefficients for which are reported in Table 4, was estimated. Although a significant number of households for whom production is observed only in one of the periods are dropped, the specification fit the data very well with an $\mathrm{R}^{2}$ of 0.76 for the fixed effect estimation, and of 0.83 for OLS with coefficient estimates from both being close to each other. Concerning the individual variables, land is estimated to be by far the most important input to crop production; doubling cultivated land area alone would lead to a $50 \%$ to $58 \%$ increase in total crop production. This is followed by seed expenditures and labor use with an estimated elasticity of $13 \%$ to $17 \%$ each. Compared to these, returns to fertilizer, pesticides, irrigation and assets are more moderate with elasticities of about 5\%, 2-3\%, 1-2\%, and $4 \%$ for expenditure on fertilizer, pesticides, irrigation and others. While neither education nor the gender of the household head are significant, land quality matters and doubling land values, which we use as a proxy for land quality, would increase total output by $11-12 \%$. Significant variation of ability across households could imply that, even without a strong pull from non-agricultural employment opportunities, the scope for market-mediated transfers to bring about efficiency gains could be large. The estimated size of technological change between the two periods is between 14 and $24 \% .^{13}$

\subsection{Determinants of land market participation}

\footnotetext{
${ }^{13}$ The fact that coefficients for the frontier production function are very similar to those obtained using OLS and the panel increases our confidence in the robustness of the results.
} 
Results from ordered probit estimation of the rental market participation equation using the pooled sample for 1982 and 1999 are reported in Table $5{ }^{14}$ The three pairs of columns correspond to our policy variables, i.e. recognition of tenants, distribution of ceiling land, and tenancy laws passed. To interpret them, recall the coding of 1 for the rent-out, 2 for the autarky, and 3 for the rent-in regime, implying that a positive coefficient will increase the probability of renting out. As ability is defined only for households or dynasties who engaged in agricultural production in both periods, inclusion of this variable reduces the sample and we also report regressions without ability in columns 1, 3 and 5.

The highly significant coefficient on ability implies that, in line with expectations, rental markets improve productivity of land use by transferring land from less to more efficient producers. The implied magnitude is large; according to the estimates, the probability for the most efficient household in the sample to rent in is more than double that for the average household as is the probability of renting out for the least efficient producer in the sample. While lack of data on profits before and after rental participation makes it difficult to assess the net impact on productivity, evidence from China, where rental helped increase productivity gains by some 60\% (Deininger and Jin 2006), suggest that these can be large.

We also find strong factor equalization effects. Higher endowments with land and limited access to family labor, especially in the 14-60 year age group, are estimated to increase the propensity to supply land to the rental market, supporting the notion that, by transferring land to labor-rich but land-poor households, markets provide scope for gainful employment of rural labor. Significance and magnitude of the coefficient on the landless dummy suggest that rental is an important avenue for landless households to access land. To interpret the coefficients, note that, at 5.4 to 8.6 percentage points above that for a land owning household, landless producer's propensity to access land through rental is almost double that of the former. The notion of land rental markets being biased in favor of the wealthy is further undermined by the lack of significance for the coefficient on total assets. ${ }^{15}$

A strong diversification effect also emerges. The head having completed at least primary education increases the propensity to rent out land, e.g. because more educated individuals have more opportunities outside of agriculture. At mean values of the other variables, the probability to rent out (rent in) land for a household whose head attained primary education or above is $2.1 \%$ higher (1.1\% lower) than one without primary education. Mean village income similarly increases the tendency to rent out, ${ }^{16}$ implying that as, with overall development, the level of income increases, households will be more likely to move out of agriculture, supply land to the rental market, and allow those with higher ability to

\footnotetext{
${ }^{14}$ As, in most states, land reform implementation was essentially completed by 1982, implementation effort after 1982 is not a good measure for states' seriousness in implementing land reform. The fact that this measure would disproportionately reward 'latecomer' states, together with the challenging econometric nature of fixed effect ordered probit estimation, leads us to use the pooled sample throughout for our estimations.

${ }^{15}$ Inclusion of an interaction between the time dummy and asset ownership (not reported) suggests that land rental markets had been biased in favor of the wealthy in 1982 but that, presumably due to better credit market access in the study areas, this bias had disappeared by 1999 .

${ }^{16}$ The coefficient on mean village income loses significance if ability is included, presumably due to the much lower number of observations.
} 
increase their holdings and income levels. This phenomenon, which has also been observed in China, highlights the importance of rental markets with economic development and suggests that imposing restrictions on the operation of such markets could not only inflict efficiency losses but also become more difficult over time.

Regarding the lower bound equation, regressions suggest that policy restrictions will lead to a significant and quantitatively large reduction of land supply to rental markets. Estimated effects are weakest for the number of laws (columns 5 and 6) and strongest for recognition of tenants (col. 1 and 2), consistent with the notion that implementation is more important than mere legislation and that landlords will be less willing to rent out if doing so can attenuate their property rights or if there are limits on their ability to negotiate the amount of rent. ${ }^{17}$ The share of land affected by redistribution of ceiling land is in the middle between these two, consistent with expectations that ceiling legislation poses less of a threat than tenancy regulation -as the latter applies to all market participants irrespective of their holding sizeand enforcing it is more politically controversial and administratively complex than implementing tenancy legislation. Coefficients on other variables suggest that, even after adjusting for policies, scheduled and backward castes are less likely to rent out land than the remainder of the population, possibly due to lower levels of social capital and less opportunity to find partners in rental markets or to enforce protection of property rights for rented land. The highly significant and positive coefficient on the 1999 dummy illustrates that, over time, land rental supply increased significantly, possibly due to information access. To quantify the impact of policy restrictions we compute, for every household, the predicted probability to rent out with actual values for all right hand side variables and with the tenancy restriction variable taking a value of zero. Taking the difference between these two values as a measure for the impact of tenancy restrictions suggests that their removal could lead to a considerable increase in renting out, by between $40 \%$ and $70 \%$.

Turning to the (upper) bound between autarky and renting in, the positive coefficient on all the policy variables suggests that over and above the reduction in supply they also depressed demand, making it more difficult for households to obtain land through rental. Across policy variables, those relating to the intensity of enforcement are again more significant; in fact the number of laws, while of the expected sign, is not different from zero at conventional levels. In most equations, coefficients are bigger for the upper as compared to the lower bound, suggesting that the impact of policy-induced restrictions will be larger on the demand side. Applying the methodology used earlier for the lower bound to assess predicted impacts of eliminating policy restrictions suggests that, with a coefficient much larger than for the upper bound, removal of tenancy restriction could double participation rates by rent-in households.

\footnotetext{
${ }^{17}$ Note that the coefficients on the number of laws and the amount of land distributed via ceiling laws lose significance in the smaller sample.
} 
Consistent with what emerged for the upper bound, we also find that backward and scheduled castes are more likely to remain in autarky and that over time, the size of the autarky area has decreased, i.e. land rental markets have become more active. While this is encouraging sign and suggests that time may partly offset undesirable impacts of rental regulation, the magnitude of the coefficients is small; estimated coefficients imply that almost a century will be required to fully offset these effects. Together with case studies suggesting that circumventing such legislation is easier for the rich than for the poor (Yugandhar 1996, Thangaraj 2004), this implies that passage of time is unlikely to eliminate the negative effects of tenancy regulation or do so in an equitable manner. To test the robustness of our conclusions, we compare results those derived from using the productivity measure derived from the frontier production function instead of the panel. Doing so increases the sample size by two thirds but leads to very similar substantive conclusions; in particular providing strong support to the factor equalization and diversification effects as well as the negative impact of policy restrictions (Appendix Table 1).

\subsection{Efficiency impact of land rental restrictions}

Results thus far highlight that policy restrictions negatively affected efficiency by reducing overall rental market and impeding access to land by the poor. Interacting policy variables with producers' estimated productive efficiency allows more detailed exploration of rental restrictions' impact on efficiency. Results from doing so, with three columns again representing three types of policy variables, are reported in Table 6 where main equation coefficients are very consistent with those reported in Table 5. The positive and significant coefficient of the interaction with tenancy and ceiling implementation in the upper bound equation (bottom panel) suggests that land rental restrictions have prevented land access by the most efficient producers.

One explanation consistent with this is that sitting tenants who already own land but are not necessarily the most efficient benefit from tenancy regulation at the cost of more productive and landpoor producers who are constrained by tenancy restrictions and unable to effectively express their demand in the market. ${ }^{18}$ Thus even if they had positive distributional effects, land rental restrictions would be difficult to justify as it should be possible to use the productivity gains form their elimination to compensate losers. The fact that, according to our analysis, this is not the case implies that an elimination of such restrictions would benefit everybody. The fact that there are likely to be further dynamic inefficiencies as the negative productivity effects from rental restrictions will accumulate over time -for example with generational shift, e.g. if children do not want to continue in farming as in the case of the Philippines (Deininger et al. 2002)- makes the case for their removal more compelling.

\footnotetext{
${ }^{18}$ The fact that interactions remain insignificant throughout in the lower bound equation -with the policy variables even losing significance for ceiling land redistribution- is not unexpected as the data do not allow us to obtain a measure of productive efficiency for all producers who rent out all their land in the second period.
} 


\section{Conclusion}

In rural India, there is an increasing recognition of the importance of land rental markets to bring land to more productive uses while at the same time providing a basis for development of the rural non-farm economy. Although the continued need for restrictions on the operation of land rental markets has been debated at an abstract level in numerous case studies, quantitative evidence of its impact has been scant, giving rise to a debate that is highly ideological in nature. Use of a national sample, jointly with crossstate variation in tenancy legislation, allows us to provide evidence on the impact of rental markets in general and restrictions on the operation of such markets in particular.

Contrary to what is often assumed, our data suggest that, by allowing higher ability individuals to access land and equalizing factor ratios, rental markets improve productivity and equity. The level of activity has increased significantly over time and wealth bias that had characterized such markets earlier evaporated as the economy has diversified. While land markets make an essential contribution to the emergence of the non-agricultural economy, rental restrictions limit the level of market activity and the ability of the most productive producers to access more land, thus reducing overall welfare. These results, which are in line with case study evidence from a number of states (Hanstad et al. 2006), highlight the importance of taking action on eliminating rental market restrictions, as articulated in the government's $10^{\text {th }} 5$-year plan (Government of India 2002) and reiterated even more forcefully in the documents circulated in preparation for the $11^{\text {th }}$ plan. ${ }^{19}$ Moreover, our results will also be of great relevance for neighboring countries, many of which have equally restrictive land rental policies that are likely to have similar impacts.

\footnotetext{
19 “...freedom in leasing of land, both 'leasing in' and 'leasing out' will help generate income for both lessee and lessor/contractor. A legislation needs to be enacted to facilitate the land utilisation by making land transactions easier and facilitating leasing and contract farming." (Government of India 2002, p. 528). Note that political resistance to abolition of tenancy restrictions can likely be minimized by taking sitting tenants' welfare into account and by proceeding in a stepwise manner, starting with states characterized by high agricultural potential, and by carefully documenting the results from doing so.
} 
Table 1: Land reform implementation in various Indian states

\begin{tabular}{lccccc} 
State & $\begin{array}{c}\text { Total agric. } \\
\text { area } \\
\text { (mn.ac) }\end{array}$ & $\begin{array}{c}\mathbf{1 9 8 0} \\
\text { Population } \\
(\mathbf{m n})\end{array}$ & $\begin{array}{c}\text { Share of } \\
\text { households } \\
\text { receiving } \\
\text { tenancy rights }\end{array}$ & $\begin{array}{c}\text { Share of area } \\
\text { redistributed } \\
\text { under ceiling } \\
\text { legislation }\end{array}$ & $\begin{array}{c}\text { Mean level of } \\
\text { land tenancy } \\
\text { laws }\end{array}$ \\
\hline Andra Pradesh & 17.11 & 75.73 & $0.75 \%$ & $8.34 \%$ & 0.53 \\
Bihar & 22.22 & 82.88 & $0.00 \%$ & $4.42 \%$ & 2.64 \\
Gujarat & 8.44 & 50.60 & $11.20 \%$ & $1.95 \%$ & 1.47 \\
Haryana & 10.60 & 21.08 & $0.01 \%$ & $1.26 \%$ & 0.00 \\
Himachal Pradesh & 2.08 & 6.08 & $3.19 \%$ & $0.06 \%$ & 1.9. \\
Karnataka & 18.79 & 52.73 & $5.29 \%$ & $1.71 \%$ & 1.42 \\
Kerala & 0.94 & 31.84 & $12.49 \%$ & $1.30 \%$ & 2.42 \\
Madhya Pradesh & 43.75 & 60.39 & $0.61 \%$ & $2.69 \%$ & 0.94 \\
Maharashtra & 33.54 & 96.75 & $10.68 \%$ & $7.74 \%$ & 0.97 \\
Orissa & 13.54 & 36.71 & $1.43 \%$ & $2.24 \%$ & 1.94 \\
Punjab & 15.45 & 24.29 & $0.04 \%$ & $1.50 \%$ & 0.58 \\
Rajasthan & 27.04 & 56.47 & $0.16 \%$ & $6.63 \%$ & 0.00 \\
Tamil Nadu & 10.12 & 62.11 & $3.23 \%$ & $2.47 \%$ & 4.03 \\
Uttar Pradesh & 51.17 & 166.05 & $0.00 \%$ & $5.81 \%$ & 1.42 \\
West Bengal & 16.98 & 80.22 & $10.80 \%$ & $14.91 \%$ & 3.83 \\
All India & 298.77 & 930.57 & $5.35 \%$ & $4.41 \%$ & 1.49 \\
\hline Source: Kaus & & & & \\
\hline
\end{tabular}

Source: Kaushik (2005), based on annual reports by the Ministry of Rural Development for columns 1-4; Besley and Burgess (2000) for column 5. 
Table 2: Key household characteristics by region and time

\begin{tabular}{|c|c|c|c|c|c|c|c|c|c|c|}
\hline & \multicolumn{5}{|c|}{1982} & \multicolumn{5}{|c|}{1999} \\
\hline & All & North & West & East & South & All & North & West & East & South \\
\hline \multicolumn{11}{|l|}{ Basic characteristics } \\
\hline Household size & 6.86 & 7.20 & 7.28 & 6.97 & 6.01 & 6.02 & 6.64 & 6.10 & 6.30 & 5.21 \\
\hline Members aged below 14 & 2.36 & 2.58 & 2.61 & 2.36 & 1.87 & 1.86 & 2.15 & 2.02 & 1.93 & 1.36 \\
\hline Members aged $14-60$ & 4.16 & 4.22 & 4.35 & 4.28 & 3.83 & 3.75 & 4.01 & 3.68 & 4.02 & 3.44 \\
\hline Members older than 60 & 0.34 & 0.41 & 0.32 & 0.33 & 0.32 & 0.41 & 0.48 & 0.40 & 0.36 & 0.41 \\
\hline Head's age & 50.10 & 51.52 & 49.59 & 48.89 & 49.96 & 49.20 & 49.45 & 48.55 & 48.43 & 50.30 \\
\hline Female head dummy (\%) & 6.86 & 4.14 & 4.39 & 4.63 & 13.29 & 6.66 & 4.28 & 5.14 & 4.65 & 11.89 \\
\hline Head with primary or above. & 0.26 & 0.22 & 0.17 & 0.26 & 0.40 & 0.50 & 0.56 & 0.42 & 0.54 & 0.51 \\
\hline Land endowment (ha) & 3.29 & 2.65 & 4.78 & 2.31 & 2.52 & 2.12 & 1.99 & 2.82 & 1.29 & 1.86 \\
\hline Land endowment p.c. & 0.52 & 0.42 & 0.72 & 0.36 & 0.42 & 0.39 & 0.35 & 0.52 & 0.24 & 0.37 \\
\hline Landless dummy (\%) & 22.28 & 22.43 & 18.78 & 20.30 & 27.02 & 23.93 & 27.16 & 21.10 & 23.41 & 25.03 \\
\hline \multicolumn{11}{|c|}{ Consumption and asset ownership } \\
\hline Per capita income & 1538.62 & 1915.45 & 1470.32 & 1226.49 & 1424.24 & 2595.59 & 2994.16 & 2125.07 & 1979.44 & 3246.56 \\
\hline Per capita consumption exp. & 1305 & 1506 & 1200 & 1058 & 1362 & 1561 & 1803 & 1526 & 1287 & 1579 \\
\hline Gini (per capita cons. exp.) & 0.32 & 0.30 & 0.29 & 0.31 & 0.36 & 0.31 & 0.31 & 0.30 & 0.36 & 0.28 \\
\hline Value of all assets (Rs.) & 17710 & 24654 & 17947 & 10170 & 14743 & 47749 & 66529 & 43810 & 29298 & 48688 \\
\hline Financial and off-farm (\%) & 26.69 & 25.73 & 29.56 & 28.30 & 23.62 & 23.21 & 18.56 & 19.87 & 25.14 & 31.66 \\
\hline Farming and livestock (\%) & 15.81 & 16.69 & 20.67 & 7.16 & 10.58 & 19.86 & 23.53 & 26.27 & 8.08 & 13.01 \\
\hline House \& cons. durables $(\%)$ & 57.50 & 57.58 & 49.79 & 64.54 & 65.79 & 56.93 & 57.91 & 53.86 & 66.78 & 55.33 \\
\hline Gini (all assets per capita) & 0.60 & 0.54 & 0.56 & 0.55 & 0.64 & 0.56 & 0.55 & 0.53 & 0.59 & 0.54 \\
\hline \multicolumn{11}{|c|}{ Participation in economic activities (\%) } \\
\hline Crop production & 70.24 & 68.57 & 75.64 & 71.49 & 65.07 & 62.89 & 67.45 & 68.41 & 61.29 & 53.15 \\
\hline Livestock production & 78.11 & 81.31 & 87.35 & 66.27 & 70.36 & 62.85 & 72.90 & 66.88 & 55.16 & 54.26 \\
\hline Non-farm self-employment & 11.33 & 10.63 & 11.16 & 13.13 & 11.22 & 10.96 & 7.86 & 10.77 & 20.73 & 7.41 \\
\hline Salaried employment & 17.47 & 24.71 & 12.65 & 22.24 & 14.18 & 17.27 & 27.33 & 13.59 & 16.22 & 13.90 \\
\hline Off-farm wage employment & 8.59 & 5.63 & 11.10 & 10.15 & 7.62 & 19.96 & 17.01 & 18.48 & 32.36 & 16.17 \\
\hline Wage employment & 37.59 & 21.27 & 39.49 & 42.69 & 47.71 & 43.29 & 28.27 & 44.98 & 53.94 & 47.05 \\
\hline No. of observation & 4980 & 1279 & 1613 & 670 & 1417 & 7476 & 1705 & 2479 & 1307 & 1985 \\
\hline
\end{tabular}

Source: Own computation from 1982 and 1999 ARIS/REDS surveys.

All values are in 1982 Rs with 1999 values having been deflated by state level deflators. 
Table 3: Key household characteristics by rental market participation status in 1982 and 1999

\begin{tabular}{|c|c|c|c|c|c|c|}
\hline & \multicolumn{3}{|c|}{1982} & \multicolumn{3}{|c|}{1999} \\
\hline & Rent-in & Autarkic & Rent-out & Rent-in & Autarkic & Rent-out \\
\hline \multicolumn{7}{|l|}{ Basic Characteristics } \\
\hline Household size & 8.15 & 6.92 & 5.34 & 6.91 & 6.04 & 5.54 \\
\hline Members aged below 14 & 2.75 & 2.38 & 1.83 & 2.38 & 1.87 & 1.53 \\
\hline Members aged $14-60$ & 4.90 & 4.20 & 3.10 & 4.17 & 3.77 & 3.45 \\
\hline Members older than 60 & 0.49 & 0.34 & 0.41 & 0.36 & 0.40 & 0.56 \\
\hline Land endowment (ha) & 2.31 & 3.34 & 2.93 & 1.27 & 2.02 & 2.87 \\
\hline Land endowment p.c. & 0.28 & 0.51 & 0.68 & 0.20 & 0.36 & 0.64 \\
\hline Landless dummy (\%) & 11.83 & 23.76 & 0.00 & 37.34 & 26.29 & 0.00 \\
\hline Head's age & 51.85 & 49.97 & 51.71 & 47.41 & 48.98 & 51.65 \\
\hline Female head dummy $(\%)$ & 2.15 & 6.67 & 12.03 & 3.30 & 6.54 & 8.90 \\
\hline Head with primary or above $(\%)$ & 29.03 & 25.34 & 35.71 & 49.50 & 48.51 & 61.53 \\
\hline \multicolumn{7}{|l|}{ Agric. production profits (Rs/ha) } \\
\hline \multicolumn{7}{|l|}{ Consumption and asset ownership } \\
\hline Per capita consumption exp. (Rs.) & 1426.98 & 1280.42 & 1697.84 & 1346.19 & 1549.19 & 2213.63 \\
\hline Value of all assets (Rs) & 34783 & 17215 & 20333 & 33839 & 46568 & 62466 \\
\hline Financial and off-farm (\%) & 19.48 & 26.47 & 34.20 & 19.23 & 22.69 & 27.160 \\
\hline Farming and livestock (\%) & 32.12 & 15.70 & 7.69 & 21.67 & 20.91 & 13.26 \\
\hline House \& cons. durables $(\%)$ & 48.40 & 57.83 & 58.10 & 59.10 & 56.41 & 59.58 \\
\hline \multicolumn{7}{|l|}{ Participation in activities (\%) } \\
\hline Crop production & 100.00 & 72.60 & 19.17 & 100.00 & 66.12 & 23.07 \\
\hline Livestock production & 97.85 & 78.66 & 61.65 & 81.82 & 63.57 & 49.88 \\
\hline Non-farm self-employment & 5.38 & 11.30 & 13.91 & 14.61 & 9.9 & 17.96 \\
\hline Salaried employment & 18.28 & 16.84 & 28.2 & 10.71 & 15.98 & 30.05 \\
\hline Wage employment & 26.88 & 38.82 & 19.92 & 59.74 & 44.93 & 23.94 \\
\hline Number of observations & 93 & 4621 & 266 & 308 & 6366 & 802 \\
\hline
\end{tabular}

Source: Own computation from 1982 and 1999 ARIS/REDS surveys

All values are in 1982 Rs; 1999 values are deflated by state level deflators. 
Table 4: Coefficient estimates for the Cobb-Douglass production function

\begin{tabular}{|c|c|c|c|}
\hline 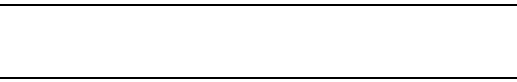 & $\begin{array}{c}\text { OLS } \\
1982 \& 1999 \text { pooled }\end{array}$ & Panel Fixed Effect & $\begin{array}{l}\text { Stochastic } \\
\text { Frontier }\end{array}$ \\
\hline Log of total crop area & $\begin{array}{c}0.499 * * * \\
(41.32)\end{array}$ & $\begin{array}{c}0.578 * * * \\
(30.33)\end{array}$ & $\begin{array}{c}0.513 * * * \\
(53.60)\end{array}$ \\
\hline Log of total labor use & $\begin{array}{c}0.173 * * * \\
(16.11)\end{array}$ & $\begin{array}{c}0.128 * * * \\
(9.19)\end{array}$ & $\begin{array}{c}0.172 * * * \\
(20.27)\end{array}$ \\
\hline Log of seed expenditure & $\begin{array}{c}0.174 * * * \\
(22.72)\end{array}$ & $\begin{array}{c}0.129 * * * \\
(12.43)\end{array}$ & $\begin{array}{c}0.148 * * * \\
(25.23)\end{array}$ \\
\hline Log of fertilizer expenditure & $\begin{array}{c}0.051 * * * \\
(12.32)\end{array}$ & $\begin{array}{c}0.047 * * * \\
(8.66)\end{array}$ & $\begin{array}{c}0.046^{* * *} \\
(14.43)\end{array}$ \\
\hline Log of pesticide expenditure & $\begin{array}{c}0.031 * * * \\
(9.41)\end{array}$ & $\begin{array}{l}0.019 * * * \\
(4.16)\end{array}$ & $\begin{array}{c}0.030 * * * \\
(10.79)\end{array}$ \\
\hline Log of irrigation and other expenditures & $\begin{array}{c}0.017 * * * \\
(4.65)\end{array}$ & $\begin{array}{c}0.012 * * \\
(2.48)\end{array}$ & $\begin{array}{c}0.019 * * * \\
(6.75)\end{array}$ \\
\hline Log of agricultural assets value & $\begin{array}{c}0.039 * * * \\
(11.83)\end{array}$ & $\begin{array}{c}0.036 * * * \\
(8.65)\end{array}$ & $\begin{array}{c}0.036^{* * * *} \\
(13.31)\end{array}$ \\
\hline Head's age & $\begin{array}{l}0.000 \\
(0.83)\end{array}$ & $\begin{array}{l}0.001 * \\
(1.75)\end{array}$ & $\begin{array}{l}0.001 \\
(1.53)\end{array}$ \\
\hline Head with primary education & $\begin{array}{l}-0.017 \\
(1.13)\end{array}$ & $\begin{array}{l}-0.030 \\
(1.35)\end{array}$ & $\begin{array}{l}-0.005 \\
(0.41)\end{array}$ \\
\hline Female headed & $\begin{array}{l}-0.036 \\
(1.09)\end{array}$ & $\begin{array}{l}-0.028 \\
(0.60)\end{array}$ & $\begin{array}{l}-0.033 \\
(1.26)\end{array}$ \\
\hline Log of land value & $\begin{array}{c}0.114 * * * \\
(12.66) \\
0.141 * * * \\
(4.97) \\
5215\end{array}$ & $\begin{array}{c}0.119 * * * \\
(9.27) \\
0.244 * * * \\
(6.55) \\
5215\end{array}$ & $\begin{array}{c}0.110^{* * *} \\
(14.61) \\
0.116^{* * *} \\
(5.06) \\
8816\end{array}$ \\
\hline R-squared & 0.84 & 0.76 & \\
\hline
\end{tabular}


Table 5: Determinants of land rental market participation

Policy measure in the upper/lower bound equations Tenants recognized Ceiling land redistributed

No. of tenancy laws

\begin{tabular}{|c|c|c|c|c|c|c|}
\hline \multicolumn{7}{|l|}{ Main equation } \\
\hline Cultivation ability & & $\begin{array}{c}0.208 * * \\
(2.50)\end{array}$ & & $\begin{array}{c}0.226 * * * \\
(2.68)\end{array}$ & & $\begin{array}{c}0.205 * * \\
(2.43)\end{array}$ \\
\hline Landless dummy & $\begin{array}{c}0.623 * * * \\
(18.09)\end{array}$ & $\begin{array}{c}0.574 * * * \\
(7.00)\end{array}$ & $\begin{array}{c}0.626^{* * *} \\
(17.81)\end{array}$ & $\begin{array}{c}0.611^{* * *} \\
(7.06)\end{array}$ & $\begin{array}{c}0.622 * * * \\
(17.91)\end{array}$ & $\begin{array}{c}0.568^{* * * *} \\
(6.84)\end{array}$ \\
\hline Land endowment (ac) & $\begin{array}{c}-0.012 * * * \\
(4.63)\end{array}$ & $\begin{array}{c}-0.024 * * * \\
(6.42)\end{array}$ & $\begin{array}{c}-0.013 * * * \\
(5.14)\end{array}$ & $\begin{array}{c}-0.024 * * * \\
(6.50)\end{array}$ & $\begin{array}{c}-0.011 * * * \\
(4.61)\end{array}$ & $\begin{array}{c}-0.024 * * * \\
(6.46)\end{array}$ \\
\hline Members below 14 years & $\begin{array}{c}0.054 * * * \\
(6.22)\end{array}$ & $\begin{array}{c}0.040 * * * \\
(3.17)\end{array}$ & $\begin{array}{c}0.055^{* * *} \\
(6.18)\end{array}$ & $\begin{array}{c}0.043 * * * \\
(3.32)\end{array}$ & $\begin{array}{c}0.056^{* * *} \\
(6.38)\end{array}$ & $\begin{array}{c}0.041 * * * \\
(3.23)\end{array}$ \\
\hline Members aged $14-60$ years & $\begin{array}{c}0.063 * * * \\
(7.97)\end{array}$ & $\begin{array}{c}0.056^{* * * *} \\
(5.28)\end{array}$ & $\begin{array}{c}0.062 * * * \\
(7.74)\end{array}$ & $\begin{array}{c}0.057^{* * *} \\
(5.28)\end{array}$ & $\begin{array}{c}0.060^{* * *} \\
(7.55)\end{array}$ & $\begin{array}{c}0.056^{* * * *} \\
(5.19)\end{array}$ \\
\hline Head's age & $\begin{array}{c}0.021 * * * \\
(3.44)\end{array}$ & $\begin{array}{c}0.031 * * * \\
(3.18)\end{array}$ & $\begin{array}{c}0.022 * * * \\
(3.62)\end{array}$ & $\begin{array}{c}0.032 * * * \\
(3.22)\end{array}$ & $\begin{array}{c}0.021 * * * \\
(3.45)\end{array}$ & $\begin{array}{c}0.031 * * * \\
(3.10)\end{array}$ \\
\hline Head's age squared/100 & $\begin{array}{c}-0.025^{* * * *} \\
(4.34)\end{array}$ & $\begin{array}{c}-0.031^{* * *} \\
(3.36)\end{array}$ & $\begin{array}{c}-0.025^{* * * *} \\
(4.36)\end{array}$ & $\begin{array}{c}-0.032 * * * \\
(3.34)\end{array}$ & $\begin{array}{c}-0.025^{* * *} \\
(4.34)\end{array}$ & $\begin{array}{c}-0.031 * * * \\
(3.28)\end{array}$ \\
\hline Head has primary or above & $\begin{array}{c}-0.148^{* * * *} \\
(4.59)\end{array}$ & $\begin{array}{c}-0.116^{* *} \\
(2.45)\end{array}$ & $\begin{array}{c}-0.153 * * * \\
(4.77)\end{array}$ & $\begin{array}{c}-0.114 * * \\
(2.42)\end{array}$ & $\begin{array}{c}-0.161 * * * \\
(4.99)\end{array}$ & $\begin{array}{c}-0.118^{* *} \\
(2.45)\end{array}$ \\
\hline Mean village income $(\log )$ & $\begin{array}{c}-0.090 * * * \\
(3.42)\end{array}$ & $\begin{array}{l}-0.037 \\
(0.96)\end{array}$ & $\begin{array}{c}-0.077 * * * \\
(2.91)\end{array}$ & $\begin{array}{l}-0.007 \\
(0.18)\end{array}$ & $\begin{array}{l}-0.072 * * * \\
(2.77)\end{array}$ & $\begin{array}{l}-0.017 \\
(0.46)\end{array}$ \\
\hline Total assets $(\log )$ & $\begin{array}{l}0.010 \\
(0.59)\end{array}$ & $\begin{array}{l}-0.008 \\
(0.30)\end{array}$ & $\begin{array}{l}0.008 \\
(0.50)\end{array}$ & $\begin{array}{l}-0.024 \\
(0.86)\end{array}$ & $\begin{array}{l}0.011 \\
(0.65)\end{array}$ & $\begin{array}{l}-0.010 \\
(0.38)\end{array}$ \\
\hline Off-farm share in total assets & $\begin{array}{c}-1.194 * * * \\
(5.43)\end{array}$ & $\begin{array}{c}-1.249 * * * \\
(2.85)\end{array}$ & $\begin{array}{c}-1.180 * * * \\
(5.24)\end{array}$ & $\begin{array}{c}-1.230 * * * \\
(2.83)\end{array}$ & $\begin{array}{c}-1.216^{* * * *} \\
(5.42)\end{array}$ & $\begin{array}{c}-1.321 * * * \\
(2.85)\end{array}$ \\
\hline \multicolumn{7}{|c|}{ Lower bound (rent out to autarky) } \\
\hline Policy variable & $\begin{array}{c}-12.300 * * * \\
(6.50)\end{array}$ & $\begin{array}{c}-13.652^{* * *} \\
(3.17)\end{array}$ & $\begin{array}{c}-1.502 * * \\
(2.53)\end{array}$ & $\begin{array}{l}-1.329 \\
(1.40)\end{array}$ & $\begin{array}{c}-0.110 * * * \\
(6.07)\end{array}$ & $\begin{array}{l}-0.043 \\
(1.41)\end{array}$ \\
\hline ST/SC dummy & $\begin{array}{c}-0.200 * * * \\
(3.85)\end{array}$ & $\begin{array}{l}-0.112 \\
(1.26)\end{array}$ & $\begin{array}{c}-0.178^{* * * *} \\
(3.38)\end{array}$ & $\begin{array}{l}-0.134 \\
(1.52)\end{array}$ & $\begin{array}{c}-0.187 * * * \\
(3.54)\end{array}$ & $\begin{array}{l}-0.133 \\
(1.51)\end{array}$ \\
\hline OBC dummy & $\begin{array}{c}-0.105 * * \\
(2.49)\end{array}$ & $\begin{array}{l}-0.068 \\
(1.04)\end{array}$ & $\begin{array}{c}-0.104 * * \\
(2.42)\end{array}$ & $\begin{array}{l}-0.068 \\
(1.02)\end{array}$ & $\begin{array}{c}-0.093 * * \\
(2.23)\end{array}$ & $\begin{array}{l}-0.068 \\
(1.03)\end{array}$ \\
\hline 1999 dummy & $\begin{array}{c}0.527 * * * \\
(8.73)\end{array}$ & $\begin{array}{c}0.778 * * * \\
(6.80)\end{array}$ & $\begin{array}{c}0.454 * * * \\
(7.49)\end{array}$ & $\begin{array}{c}0.719 * * * \\
(6.38)\end{array}$ & $\begin{array}{c}0.451^{* * *} \\
(7.53)\end{array}$ & $\begin{array}{c}0.744 * * * \\
(6.68)\end{array}$ \\
\hline \multicolumn{7}{|c|}{ Upper bound (autarky to rent in) } \\
\hline Policy variable & $\begin{array}{c}12.697 * * * \\
(4.18)\end{array}$ & $\begin{array}{c}24.871 * * * \\
(3.96)\end{array}$ & $\begin{array}{c}2.551 * * * \\
(2.71)\end{array}$ & $\begin{array}{c}6.829 * * * \\
(3.86)\end{array}$ & $\begin{array}{l}0.018 \\
(0.90)\end{array}$ & $\begin{array}{l}0.008 \\
(0.24)\end{array}$ \\
\hline ST/SC dummy & $\begin{array}{c}0.166^{* *} \\
(2.52)\end{array}$ & $\begin{array}{c}0.255^{* *} \\
(2.43)\end{array}$ & $\begin{array}{c}0.148^{* *} \\
(2.24)\end{array}$ & $\begin{array}{c}0.313^{* * *} \\
(2.89)\end{array}$ & $\begin{array}{c}0.165 * * \\
(2.52)\end{array}$ & $\begin{array}{c}0.312 * * * \\
(2.97)\end{array}$ \\
\hline OBC dummy & $\begin{array}{c}0.148 * * \\
(2.42)\end{array}$ & $\begin{array}{c}0.223 * * * \\
(2.79)\end{array}$ & $\begin{array}{l}0.116^{*} \\
(1.87)\end{array}$ & $\begin{array}{c}0.194 * * \\
(2.39)\end{array}$ & $\begin{array}{c}0.147 * * \\
(2.42)\end{array}$ & $\begin{array}{c}0.239 * * * \\
(3.03)\end{array}$ \\
\hline 1999 dummy & $\begin{array}{c}-0.239 * * * \\
(3.41)\end{array}$ & $\begin{array}{l}-0.074 \\
(0.71)\end{array}$ & $\begin{array}{c}-0.245^{* * * *} \\
(3.43)\end{array}$ & $\begin{array}{l}-0.113 \\
(1.10)\end{array}$ & $\begin{array}{c}-0.258^{* * * *} \\
(3.69)\end{array}$ & $\begin{array}{l}-0.126 \\
(1.25)\end{array}$ \\
\hline Observations & 11331 & 5303 & 11147 & 5303 & 11221 & 5237 \\
\hline Log likelihood & -4564.94 & -1985.13 & -4450.96 & -1986.69 & -4514.77 & -1976.77 \\
\hline
\end{tabular}


Table 6: Ordered probit regression interacting policy with efficiency measures

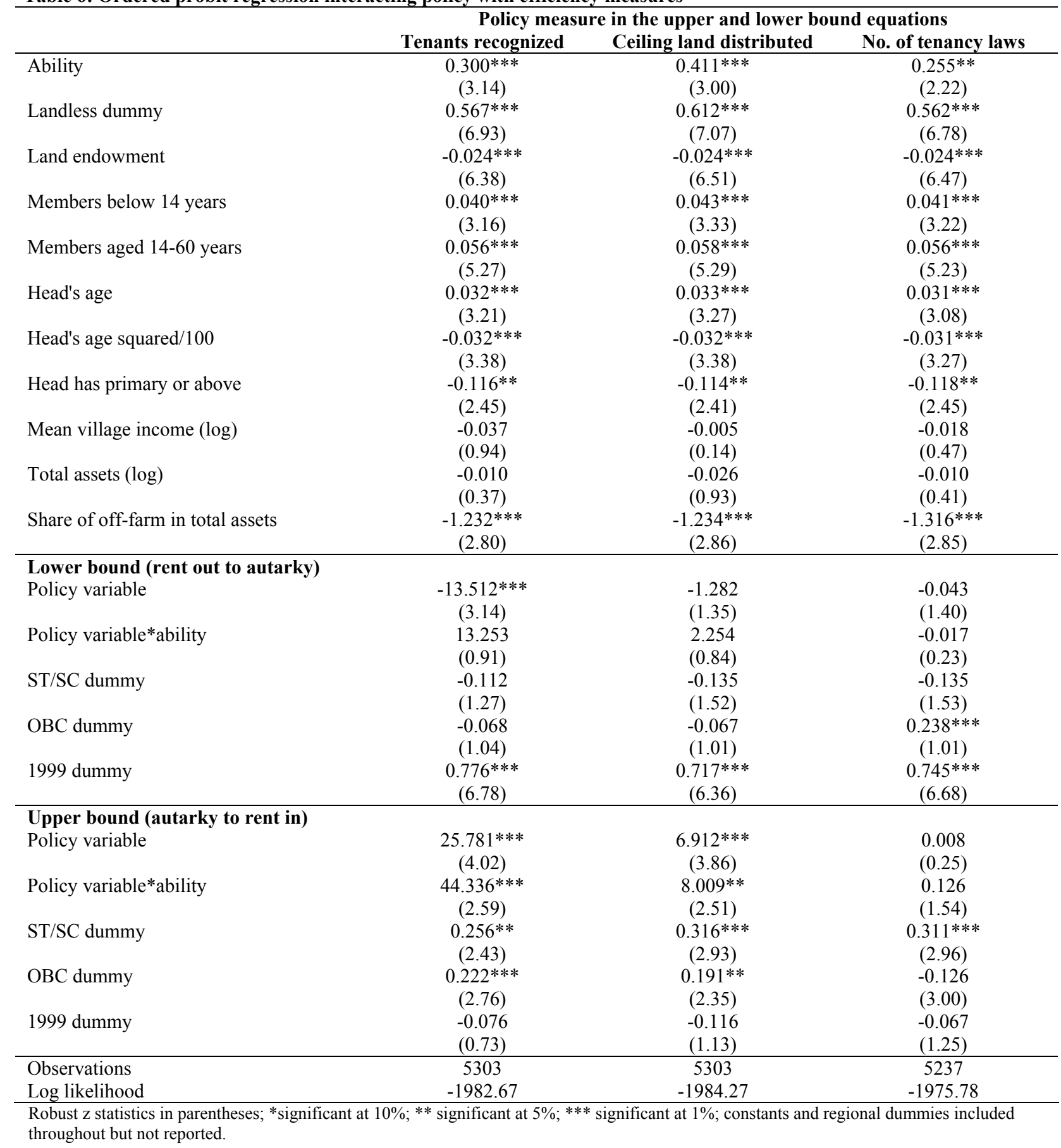




\section{Annex 1: Proofs for main propositions}

Proposition 1: The amount of land rented in (out) is strictly increasing (decreasing) in households' agricultural ability $\alpha_{\mathrm{i}}$, and strictly decreasing (increasing) in the land endowment $\bar{A}_{i}$. Rental markets will transfer land to efficient, but land-poor producers, thereby contributing to higher levels of productivity and more efficient factor use in the overall economy.

Total differentiation of both sides of (2) with respect to $\alpha$ yields

$$
p f_{l_{a} \alpha}\left(\alpha, l_{a}, A\right)+p\left(f_{l_{a} l_{a}} \frac{\partial l_{a}}{\partial \alpha}+f_{l_{a} A} \frac{\partial A}{\partial \alpha}\right)=0
$$

Similarly, total differentiation of both sides of (3) or (4) with respect to $\alpha$, yields:

$$
p f_{A \alpha}\left(\alpha, l_{a}, A\right)+p\left(f_{A A} \frac{\partial A}{\partial \alpha}+f_{A l_{a}} \frac{\partial l_{a}}{\partial \alpha}\right)=0
$$

From (A1), we can obtain $\partial l_{a} / \partial \alpha$; substituting this into (A2) gives, after some manipulation of terms

$$
\frac{\partial A^{*}}{\partial \alpha}=\frac{f_{A l_{a}} f_{l_{a} \alpha}-f_{A} f_{l_{a} l_{a}}}{\left(f_{A A} f_{l_{a} l_{a}}-f_{A l_{a}} f_{l_{a} A}\right)}=\frac{f_{A l_{a}} f_{l_{a} \alpha}-f_{A \alpha} f_{l_{a} l_{a}}}{\left[f_{A A} f_{l_{a} l_{a}}-\left(f_{A l_{a}}\right)^{2}\right]}>0
$$

Thus, for all households who participate on either side of rental markets, area operated increases with ability. The amount of land rented in or out can be expressed as the difference between operational area and the household's land endowment,

$$
a^{\text {in }}=A^{*}-\bar{A} \text { and } a^{\text {out }}=\bar{A}-A^{*}
$$

Total differentiation of both sides of (A4) with respect to $\alpha$ yields $\frac{\partial a^{\text {in }}}{\partial \alpha}=\frac{\partial A^{*}}{\partial \alpha}>0$ and $\frac{\partial a^{\text {out }}}{\partial \alpha}=-\frac{\partial A^{*}}{\partial \alpha}<0$, implying that amount of land rented in (or out) is increasing (deceasing) in agricultural ability.

Total differentiation of both sides of (A4) with respect to $\bar{A}$, yield $\frac{\partial a^{\text {in }}}{\partial \bar{A}}=-1<0$ and $\frac{\partial a^{\text {out }}}{\partial \bar{A}}=1>0$, implying the amount of land rented in (or out) is strictly decreasing (or increasing) in land endowment.

Proposition 2: The presence of transaction costs defines two critical ability levels $\alpha_{1}\left(\mathrm{TC}^{\text {out }}, ..\right)$ and $\alpha_{\mathrm{u}}\left(\mathrm{TC}^{\mathrm{in}}, ..\right)$ such that households with ability $\alpha_{i} \in\left[\alpha_{1}, \alpha_{u}\right]$ will remain in autarky. Any increase in $\mathrm{TC}^{\text {in }}$ or TC $^{\text {out }}$ will expand the autarky range, thereby reducing the number of producers participating in rental markets and thus the number of efficiencyenhancing land transactions. Compared to a situation with no transaction cost, this will decrease productivity and social welfare.

Using the functional form $f\left(\alpha, l_{a}, A\right)=\alpha^{1-\beta_{1}-\beta_{2}} l_{a}^{\beta_{1}} A^{\beta_{2}}$ for the production function, FOC (2-4) can be rewritten as: 


$$
p \beta_{1} \alpha^{1-\beta_{1}-\beta_{2}} l_{a}^{\beta_{1}-1} A^{\beta_{2}}=w
$$

and for households who rented in: $p \beta_{2} \alpha^{1-\beta_{1}-\beta_{2}} l_{a}^{\beta_{1}} A^{\beta_{2}-1}=r+T C^{i n}$

for households who rented out: $\quad p \beta_{2} \alpha^{1-\beta_{1}-\beta_{2}} l_{a}^{\beta_{1}} A^{\beta_{2}-1}=r-T C^{i n}$

Substituting $A=\bar{A}$ into (A5) yields

$$
l_{a}^{*}=\left(\frac{w}{p \beta_{1} \alpha^{1-\beta_{1}-\beta_{2}} \bar{A}^{\beta_{2}-1}}\right)^{\frac{1}{\beta_{1}-1}}
$$

Substituting $l_{a}=l_{a}^{*}$ and $A=\bar{A}$ into (A7) allow us to derive $\alpha_{l}=\left(\frac{r-T C^{o u t}}{\beta_{2}\left(l_{a}^{*}\right)^{\beta_{1}} \bar{A}^{\beta_{2}-1}}\right)^{\frac{1}{1-\beta_{1}-\beta_{2}}}$

Similarly, substituting $l_{a}=l_{a}^{*}$ and $A=\bar{A}$ into (A6) yields $\alpha_{u}=\left(\frac{r+T C^{i n}}{\beta_{2}\left(l_{a}^{*}\right)^{\beta_{1}} \bar{A}^{\beta_{2}-1}}\right)^{\frac{1}{1-\beta 1-\beta 2}}$

Straightforward differentiation then yields $\partial \alpha_{1} / \partial \mathrm{TC}^{\text {out }}<0$ and $\partial \alpha_{\mathrm{u}} / \partial \mathrm{TC} \mathrm{in}^{\mathrm{in}}>0$, implying that increased transaction costs will reduce the number of producers participating in rental markets and the reverse.

Proposition 3: Increases of the wage for off-farm employment will increase the amounts of land transacted in rental markets by increasing the amount rented out by households with low agricultural ability -who as a consequence will join the off-farm labor market- and the amount rented in by those with high-ability who specialize in agricultural production. This will be associated with a decrease in the equilibrium rental rate which, in a risk-free environment, will make everybody better off.

First, we consider the case where there is no minimum labor $\left(l_{a}^{c}\right)$ below which households quit farming.

Obtaining $l_{a}=r^{\left(\frac{1}{\beta_{2}}\right)} \beta_{1}^{\left(-\frac{1}{\beta_{2}}\right)} \alpha^{\left(\frac{1-\beta_{1}-\beta_{2}}{-\beta_{2}}\right)} A^{\left(\frac{1-\beta_{1}}{\beta_{2}}\right)}$ from (7) and substituting it into (6) yields, after some manipulation,

$$
A^{*}=\alpha w^{\left(\frac{\beta_{2}}{\beta_{1}+\beta_{2}-1}\right)} \beta_{2}^{\left(\frac{\beta_{2}}{1-\beta_{1}-\beta_{2}}\right)} \beta_{1}^{\left(\frac{\beta_{2}-1}{\beta_{1}+\beta_{2}-1}\right)} r^{\left(\frac{1-\beta_{2}}{\beta_{1}+\beta_{2}-1}\right)}
$$

This implies suggesting that the optimal operational land size is proportional to farming ability. Denoting by $\Delta$ the second part of this expression allows us to rewrite this as $\quad \mathrm{A}^{*}=\alpha \Delta$

With $n$ agents, the total amount of land in the economy is $n \bar{A}$, yielding the land market clearing condition $\int_{\underline{\alpha}}^{\bar{\alpha}} \alpha \Delta d \alpha=n \bar{A}$ which we can use to obtain an expression for $\Delta \Delta=\frac{2 n \bar{A}}{\bar{\alpha}^{2}-\underline{\alpha}^{2}}$. Substituting this expression back into (A12) allows to solve for $\mathrm{A}^{*}$, and thus for $l_{a}{ }^{*}$, and $r^{*}$. Specifically, we have:

$$
A^{*}=\alpha \frac{2 n \bar{A}}{\left(\bar{\alpha}^{2}-\underline{\alpha}^{2}\right)}, l_{a}^{*}=\alpha\left(\frac{\bar{\alpha}^{2}-\underline{\alpha}^{2}}{2 n \bar{A}}\right)^{\left(\frac{\beta_{1}}{\beta_{2}-1}\right)} w^{\left(\frac{1}{\beta_{2}-1}\right)} \beta_{2}^{\left(\frac{1}{1-\beta_{2}}\right)} \text { and } r^{*}=\left(\frac{\bar{\alpha}^{2}-\alpha^{2}}{2 n \bar{A}}\right)^{\left(\frac{\beta_{1}+\beta_{2}-1}{\beta_{2}-1}\right)} w^{\left(\frac{1}{\beta_{2}-1}\right)} \beta_{2}^{\left(\frac{1}{1-\beta_{2}}\right)} \beta_{1} .
$$


Now assume that all those who optimally would supply a level of farm labor below a critical threshold $\left(l_{a}^{c}\right)$ will be better off exiting agriculture altogether and renting out all of their land. To solve this problem, note that, due to the monotonic relationship between both variables implied by $\partial l_{a}{ }^{*} / \partial \alpha>0$, it will suffice to find the critical level of ability $\alpha_{c}$ that corresponds to this threshold so that households with ability $\alpha<\alpha_{c}$ will have $l_{a}{ }^{*}<l_{a}^{c}$ and rent out all their land. Setting $l_{a}^{*}=l_{a}^{c}$ and manipulating terms allows us to solve for $\alpha_{c}$ as

$$
\alpha_{c}=\left(\frac{\bar{\alpha}^{2}-\underline{\alpha}^{2}}{2 n \bar{A}}\right)^{\left(\frac{\beta_{1}}{1-\beta_{2}}\right)} w^{\left(\frac{1}{1-\beta_{2}}\right)} \beta_{2}^{\left(\frac{1}{\beta_{2}-1}\right)} l_{a}^{c}
$$

As, by assumption, only households with $\alpha \in\left[\alpha_{c}, \bar{\alpha}\right]$ will remain in cultivation, the new market clearing condition will be $\int_{\alpha_{c}}^{\bar{\alpha}} \alpha \Delta d \alpha=n \bar{A}$. Substitution of $a_{c}$ from (A13) into the market clearing condition allows us to obtain an expression for the optimal operational land size $\mathrm{A}^{* *}$ in this situation.

$$
A^{*}=\alpha \frac{2 n \bar{A}}{\bar{\alpha}^{2}-\left(\frac{\bar{\alpha}^{2}-\underline{\underline{\alpha}}^{2}}{2 n \overline{\bar{A}}}\right)^{\left(\frac{2 \beta_{1}}{1-\beta_{2}}\right)} w_{w^{\left(\frac{2}{1-\beta_{2}}\right)}}^{\beta_{2}\left(\frac{2}{\beta_{2}-1}\right) l_{a}^{c}}}
$$

Setting $\mathrm{A}^{* *}=\bar{A}$ allows us to solve for the level of ability $\alpha_{\mathrm{au}}$ that separates households who rent-in (for $\alpha_{\mathrm{i}}>\alpha_{\mathrm{au}}$ ) from those who rent out $\left(\alpha_{\mathrm{i}}<\alpha_{\mathrm{au}}\right)$

$$
\alpha_{a u}=\frac{\bar{\alpha}^{2}-\left(\frac{\bar{\alpha}^{2}-\underline{\alpha}^{2}}{2 n \bar{A}}\right)^{\left(\frac{2 \beta 1}{1-\beta_{2}}\right)} w^{\left(\frac{2}{1-\beta_{2}}\right)} \beta_{2}^{\left(\frac{2}{\beta_{2}-1}\right)} l_{a}^{c}}{2 n}
$$

Noting that the right hand side of (A11) and (A14) will be identical allow us to solve for the new equilibrium rental rate $\mathrm{r}^{* *}$ which can be explicitly solved for after some manipulation but which we omit for space reasons and since it is not particularly informative in our context.

Simple differentiation of the expressions derived above then yields $\frac{\partial A^{* *}}{\partial w}>0, \frac{\partial \alpha_{a u}}{\partial w}<0, \frac{\partial \alpha_{c}}{\partial w}>0$ and $\frac{\partial r^{* *}}{\partial w}<0$, all of which suggest that, as off-farm opportunities increase a larger number of households will leave agriculture and rent out all their land endowment, that households who remain in agricultural production will cultivate more land, more households will rent in land, and the equilibrium rental rate will decrease. 
Appendix Table 1: Determinants of land rental participation using alternative ability measure

Policy measure in the upper/lower bound equations Tenants recognized Ceiling land redistributed No. of tenancy laws

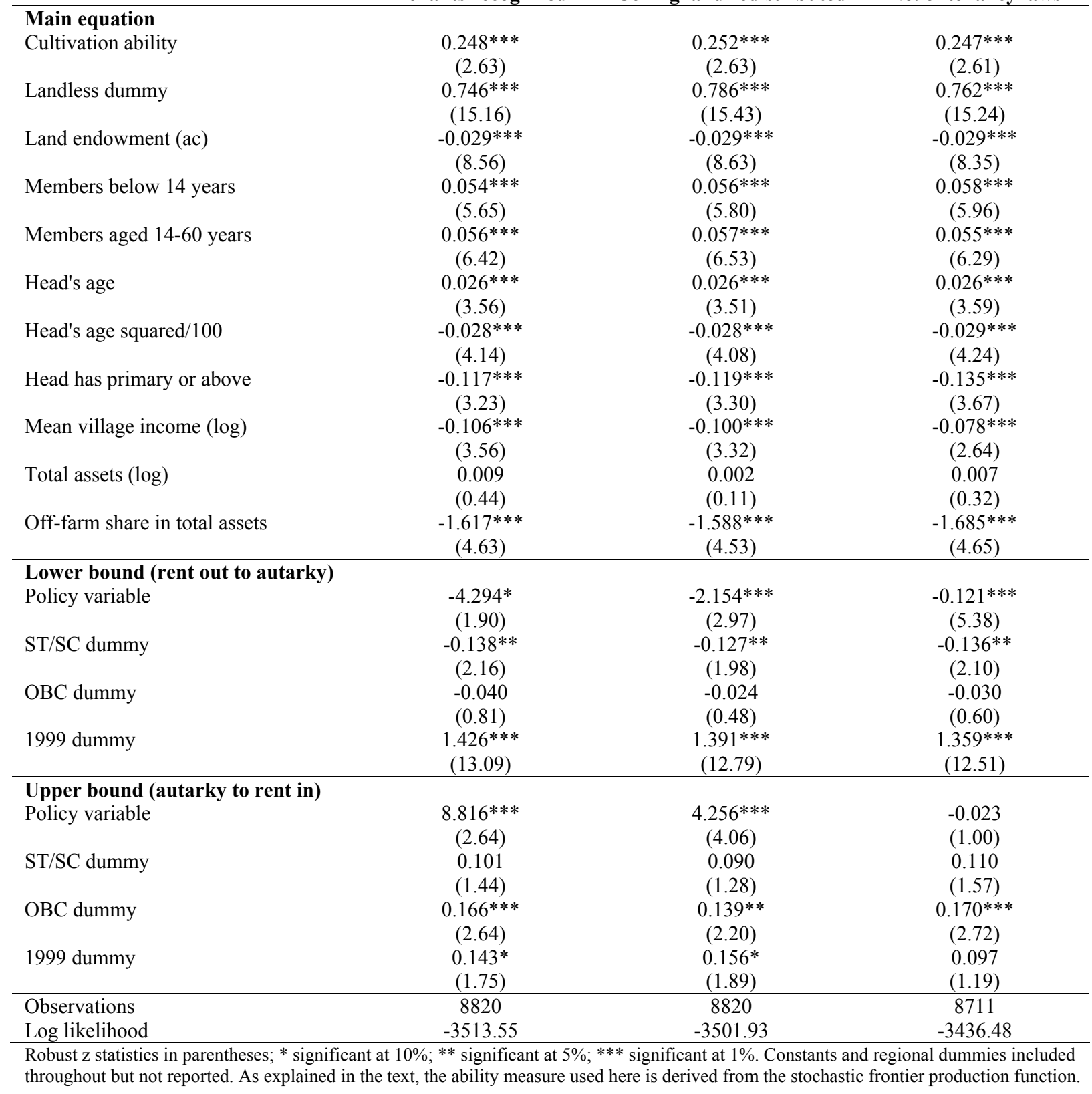


References:

Aghion, P., E. Caroli and C. Garcia-Penalosa. 1999. "Inequality and Economic Growth: The Perspective of the New Growth Theories." Journal of Economic Literature 37 (4): 1615-60.

Alston, L. J. and J. P. Ferrie. 2005. "Time on the Ladder: Career Mobility in Agriculture, 1890-1938." NBER Working Paper 11231. Cambridge MA: National Bureau of Economic Research.

Appu, P. S. 1997. Land Reforms in India: A Survey of Policy, Legislation and Implementation. New Delhi: Vikas Publishing House.

Arnott, R. 2003. "Tenancy rent control." Swedish Economic Policy Review 10 (1): 89-121.

Banerjee, A. and L. Iyer. 2005. "History, Institutions, and Economic Performance: The Legacy of Colonial Land Tenure Systems in India." American Economic Review 95 (4): 1190-213.

Banerjee, A. V., P. J. Gertler and M. Ghatak. 2002. "Empowerment and Efficiency: Tenancy Reform in West Bengal." Journal of Political Economy 110 (2): 239-80.

Basu, K. and P. M. Emerson. 2000. "The Economics of Tenancy Rent Control." Economic Journal 110 (466): 939-62.

Basu, K. and P. M. Emerson. 2003. "Efficiency Pricing, Tenancy Rent Control and Monopolistic Landlords." Economica 70 (278): 223-32.

Besley, T. and R. Burgess. 2000. "Land Reform, Poverty Reduction, and Growth: Evidence from India." Quarterly Journal of Economics 115 (2): 389-430.

Besley, T. and R. Burgess. 2004. "Can Labor Regulation Hinder Economic Performance? Evidence from India." Quarterly Journal of Economics 119 (1): 91-134.

Binswanger, H. P., K. Deininger and G. Feder. 1995. "Power, Distortions, Revolt and Reform in Agricultural Land Relations." Handbook of development economics $3 B$ 2659-772.

Carter, M. R. and Y. Yao. 2002. "Local versus Global Separability in Agricultural Household Models: The Factor Price Equalization Effect of Land Transfer Rights." American Journal of Agricultural Economics 84 (3): 702-15.

Coelli, T. J. 1995. "Recent Developments in Frontier Modelling and Efficiency Measurement." Australian Journal of Agricultural Economics 39 (3): 219-45.

Conning, J. H. and J. A. Robinson. 2007. "Property rights and the political organization of agriculture." Journal of Development Economics 82 (2): 416-47.

Deininger, K., M. Maertens, P. Olinto, and F. Lara. 2002. "Redistribution, Investments and Human Capital Accumulation: The Case of Agrarian Reform in the Philippines." World Bank Discussion Paper. Washington D.C.

Deininger, K. 2003. Land policies for growth and poverty reduction World Bank Policy Research Report series. Washington, D.C.: World Bank; Oxford and New York: Oxford University Press.

Deininger, K. and S. Jin. 2005. "The potential of land markets in the process of economic development: Evidence from China." Journal of Development Economics 78 (1): 241-70.

Deininger, K. and S. Jin. 2007. "Land Sales and Rental Markets in Transition: Evidence from Rural Vietnam." Oxford Bulletin of Economics and Statistics forthcoming.

Foster, A. D. and M. R. Rosenzweig. 1996. "Comparative advantage, information and the allocation of workers to tasks: Evidence from an agricultural labor market." University of Pennsylvania .

Foster, A. D. and M. R. Rosenzweig. 2004. "Agricultural Productivity Growth, Rural Economic Diversity, and Economic Reforms: India, 1970-2000." Economic Development and Cultural Change 52 (3): 509-42.

Frisvold, G. B. 1994. "Does Supervision Matter? Some Hypothesis Tests using Indian Farm-Level Data." Journal of Development Economics 43 (2): 217-38.

Glaeser, E. L. 2002. "Does rent control reduce segregation?" HIER Discussion Paper 1985. Cambridge MA: Harverd University. Government of India. 2002. "10 $0^{\text {th }}$ Five Year Plan (2002-2007)." . New Delhi: Planning Commision.

Gyourko, J. and P. Linneman. 1990. "Rent Controls and Rental Housing Quality: A Note on the Effects of New York City's Old Controls." Journal of Urban Economics 27 (3): 398-409.

Hanstad, T., T. Haque, and R. Nielsen. 2006. "Improving Land Access for India's Rural Poor." . New Delhi: Paper presented at the MoRD/World Bank workshop on "Land Policies for Accelerated Growth and Poverty Reduction in India", Jan. 5 and 6, 2006. 
Kaushik, A. 2005. "Nature of land market interventions in India." Institute for Sustainable Development Noida.

King, R. 1977. Land Reform: a World Survey. London: G.Bell and Sons.

Malpezzi, S. and G. Ball. 1991. "Rent control in developing countries." World Bank Discussion Papers, no. 129. Washington DC: World Bank.

Moog, R. S. 1997. Whose interests are supreme? Organizational politics in the civil courts in India. Ann Arbor, Michigan: Association for Asian Studies.

Munch, J. R. and M. Svarer. 2002. "Rent Control and Tenancy Duration." Journal of Urban Economics 52 (3): $542-60$.

Mundlak, Y. 1961. "Production functions free of management bias." Journal of Farm Economics 43 (3): 414-35.

Spillman, W. J. 1919. "The agricultural ladder." American Economic Review 9 (1): 170-9.

Thangaraj, M. 2004. Land reforms in India. Volume 9. Tamil Nadu--An unfinished task New Delhi; Thousand Oaks, Calif. and London: Sage Publications.

Thorner, D. 1976. Agrarian Prospect in India. New Delhi: Allied Publishers.

Warriner, D. 1969. Land Reform in Principle and Practice. Oxford: Clarendon Press.

World Bank. 2005. "World Development Report 2006: Equity and Development." . Washington, DC: The World Bank and Oxford University Press.

World Bank. 2007. "India: Land policies for growth and poverty reduction." . New Delhi: World Bank Agriculture and Rural Development Sector Unit South Asia Region and Oxford University Press.

Yugandhar, B. N. 1996. Land reforms in India. Volume 3. Andhra Pradesh--People's pressure and administrative innovations New Delhi; Thousand Oaks, Calif. and London: Sage Publications. 